\title{
Golli Myelin Basic Proteins Regulate Oligodendroglial Progenitor Cell Migration through Voltage-Gated $\mathrm{Ca}^{2+}$ Influx
}

\author{
Pablo M. Paez, ${ }^{1}$ Daniel J. Fulton, ${ }^{1}$ Vilma Spreuer, ${ }^{1}$ Vance Handley, ${ }^{1}$ Celia W. Campagnoni, ${ }^{1}$ Wendy B. Macklin, ${ }^{2}$ \\ Christopher Colwell, ${ }^{1}$ and Anthony T. Campagnoni ${ }^{1}$ \\ ${ }^{1}$ Semel Institute for Neuroscience and Human Behavior, David Geffen School of Medicine at UCLA, Los Angeles Medical School, Los Angeles, California \\ 90095, and ${ }^{2}$ Department of Neurosciences, Lerner Research Institute, Cleveland Clinic, Cleveland, Ohio 44195
}

\begin{abstract}
Migration of oligodendrocyte progenitor cells (OPCs) from proliferative zones to their final location in the brain is an essential step in nervous system development. Golli proteins, products of the myelin basic protein gene, can modulate voltage-gated $\mathrm{Ca}^{2+}$ uptake in OPCs during process extension and retraction. Given the importance of process extension/retraction on movement, the consequences of golli expression on OPC migration were examined in vivo and in vitro using time-lapse imaging of isolated OPCs and acute brain slice preparations from golli KO and golli J37 overexpressing mice (JOE). The results indicated that golli stimulated migration, and this enhanced motility was associated with increases in the activity of voltage operated $\mathrm{Ca}^{2+}$ channels (VOCCs). Activation of VOCCs by high $\mathrm{K}^{+}$resulted in a significant increase in the migration speed of JOE OPCs versus control cells and golli-mediated modulation of OPC migration disappeared in the presence of VOCC antagonists. During migration, OPCs generated $\mathrm{Ca}^{2+}$ oscillations that were dependent on voltage-calcium influx and both the amplitude and frequency of these $\mathrm{Ca}^{2+}$ transients correlated positively with the rate of cell movement under a variety of pharmacological treatments. The $\mathrm{Ca}^{2+}$ transient amplitude and the rate of cell movement were significantly lower in KO cells and significantly higher in JOE cells suggesting that the presence of golli promotes OPC migration by increasing the size of voltage-mediated $\mathrm{Ca}^{2+}$ oscillations. These data define a new molecule that regulates $\mathrm{Ca}^{2+}$ homeostasis in OPCs, and are the first to demonstrate that voltage-gated $\mathrm{Ca}^{2+}$ channels can regulate an OPC function, such as migration.
\end{abstract}

\section{Introduction}

The myelin basic protein (MBP) gene encodes two families of proteins: the "classic" MBPs and the golli proteins (Campagnoni et al., 1993; Pribyl et al., 1993). Unlike the classic MBPs, golli proteins are expressed in both myelin-forming cells and neurons in the CNS (Landry et al., 1996; Pribyl et al., 1996). Golli proteins first appear in many neurons when they are extending processes for migration, establishing connections and, in the case of OLs, before myelination (Landry et al., 1996; Pribyl et al., 1996). Myelination is clearly disturbed in animal models in which expression of golli proteins have been perturbed in oligodendrocytes (OLs) (Jacobs et al., 2005; Martin et al., 2007). Golli knockout $(\mathrm{KO})$ animals exhibit delayed and reduced myelination in regions of the brain, such as the visual cortex and forebrain; and primary cultures of OPCs from golli KO mice exhibit impaired formation of myelin sheets. In golli overexpressing mice, called JOE (for J37 golli OverExpressor) in which the golli J37 isoform is

Received Dec. 5, 2008; revised April 9, 2009; accepted April 17, 2009.

This work was sponsored by the National Institutes of Health Grants NS23022 and NS33091, and supported (in part) by a Postdoctoral Fellowship from the National Multiple Sclerosis Society, FG1723A1/1. We thank Dr. Veronica T. Cheli for assistance in the figure preparation.

Correspondence should be addressed to Anthony T. Campagnoni, Semel Institute for Neuroscience and Human Behavior, David Geffen School of Medicine at UCLA, Neuroscience Research Building, 635 Charles Young Drive, Los Angeles, CA 90095-7332. E-mail: acampagnoni@mednet.ucla.edu.

DOI:10.1523/JNEUROSCI.5806-08.2009

Copyright $\odot 2009$ Society for Neuroscience $\quad$ 0270-6474/09/296663-14\$15.00/0 overexpressed specifically in OLs under the control of a classic MBP promoter, hemizygous animals develop an intention tremor around P15 that persists until $\sim$ P60. During this period, biochemical, morphological and MRI imaging studies indicate that the JOE CNS is severely hypomyelinated (Reyes et al., 2003; Martin et al., 2007).

Recent findings indicate that golli proteins play a role in regulating $\mathrm{Ca}^{2+}$ influx in T cells and in primary OPC cultures (Jacobs et al., 2005; Feng et al., 2006). Overexpression of golli in OL cell lines induced the elaboration of sheets and processes (Reyes and Campagnoni, 2002; Paez et al., 2007); and $\mathrm{Cd}^{2+}$, a specific blocker of voltage operated $\mathrm{Ca}^{2+}$ channels (VOCCs), abolished the ability of golli to promote this process extension (Paez et al., 2007). Additionally, high resolution spatiotemporal analysis along OPC processes, revealed higher amplitude local $\mathrm{Ca}^{2+}$ influx in regions with elevated levels of golli (Paez et al., 2007). Live imaging of the OL cell lines overexpressing golli revealed a dramatic and fast retraction of the processes and sheets on depolarization with high $\mathrm{K}^{+}$. This phenomenon was associated with a significant increase in $\mathrm{Ca}^{2+}$ influx. These findings suggest a role for golli proteins in modulating process extension and retraction in OPCs through the participation of voltage-gated $\mathrm{Ca}^{2+}$ channels.

During development, OPCs migrate relatively long distances from germinal sites throughout the CNS (Warrington et al., 1993; Goldman et al., 1997; Schmidt et al., 1997). Multiple events in- 
volved in OPC migratory activity have been reported to be $\mathrm{Ca}^{2+}$ sensitive (Fay, 1995; Kohama et al., 1996; Pedrosa Ribeiro et al., 1997). Recently, Gudz et al. (2006) demonstrated that an increase in amplitude and frequency of $\mathrm{Ca}^{2+}$ transients is one mechanism underlying AMPA-induced stimulation of OPC migration. In general, however, the role of $\mathrm{Ca}^{2+}$ transients on glial cell migration remains largely unknown.

Golli appears to play a role in the extension and retraction of OPC processes through $\mathrm{Ca}^{2+}$-mediated events (Paez et al., 2007). Given the importance of process extension/retraction on movement it might be expected that golli could influence OPC migration. Here we tested that hypothesis by correlating subcellular $\mathrm{Ca}^{2+}$ changes with the migration rates of OPCs from control, golli $\mathrm{KO}$ and JOE mice both in primary cell cultures, and in tissue slice preparations. Increased golli expression was associated with enhanced OPC motility, and this effect was accompanied by increases in the amplitude of spontaneous somatic $\mathrm{Ca}^{2+}$ transients. These results demonstrate a unique impact of golli proteins on OPC migration that involves modulation of $\mathrm{Ca}^{2+}$ uptake via voltage-gated $\mathrm{Ca}^{2+}$ channels.

\section{Materials and Methods \\ Transgenic mice}

Golli KO mouse. We previously generated a golli knock-out (KO) mouse in which the golli products of the MBP gene were selectively ablated while permitting normal expression of the classic MBPs (Jacobs et al., 20005). Through non-brother-sister crosses, a line was generated that is homozygous for the golli ablation on a background that is 50\% 129S7/ SvEvBrd and 50\% C57BL/6J. A control line (KO Control) was established that was also $50 \% 129 \mathrm{~S} 7 / \mathrm{SvEvBrd}$ and $50 \% \mathrm{C} 57 \mathrm{BL} / 6 \mathrm{~J}$ but was negative for the golli ablation. The golli KO phenotype was observed before keeping the lines separate and then was studied over at least eight generations and remained stable.

JOE mouse. We generated a transgenic mouse that overexpresses the golli isoform J37 in oligodendrocytes under the control of a classic MBP promoter (Martin et al., 2007). In this transgenic mouse, the J37 golli isoform is driven by a $1.9-\mathrm{kb}$ region of the classic MBP promoter, thus directing overexpression of the protein specifically to OLs in the CNS. These mice are called JOE mice for golli J37 OverExpressing. A line was generated that is heterozygous for the MBP 1.9-J37 transgene on a background that is $50 \% \mathrm{BALB} / \mathrm{cByJ}, 37-50 \% \mathrm{C} 57 \mathrm{BL} / 6$, and 0 to $12 \% \mathrm{C} 3 \mathrm{H} / \mathrm{He}$. A control line (JOE Control) was established that was also 50\% BALB/ cByJ, 37-50\% C57BL/6, and 0 to $12 \% \mathrm{C} 3 \mathrm{H} / \mathrm{He}$.

\section{Primary cultures of cortical oligodendrocytes}

Enriched oligodendrocytes from control, golli KO and JOE mice were prepared as described by Amur-Umarjee et al. (1993). First, cerebral hemispheres from 1-d-old mice were mechanically dissociated and were plated on poly-D-lysine-coated flasks in DMEM and Ham's F12 (1:1 v/v) (Invitrogen), containing $100 \mu \mathrm{g} / \mathrm{ml}$ gentamicin and supplemented with $4 \mathrm{mg} / \mathrm{ml}$ dextrose anhydrous, $3.75 \mathrm{mg} / \mathrm{ml}$ HEPES buffer, $2.4 \mathrm{mg} / \mathrm{ml} \mathrm{so}$ dium bicarbonate and 10\% fetal bovine serum (FBS) (Omega Scientific). After $24 \mathrm{~h}$ the medium was changed and the cells were grown in DMEM/ F-12 supplemented with insulin $(5 \mu \mathrm{g} / \mathrm{ml})$, transferring $(50 \mu \mathrm{g} / \mathrm{ml})$, sodium selenite $(30 \mathrm{nM}), \mathrm{T}_{3}(15 \mathrm{nM})$, D-Biotin $(10 \mathrm{~mm})$, hydrocortisone (10 nм), 0.1\% BSA (Sigma-Aldrich), 1\% horse serum and 1\% FBS (Omega Scientific). After $9 \mathrm{~d}$, OLs were purified from the mixed glial culture by the differential shaking and adhesion procedure by Suzumura et al. (1984) and allowed to grow for $24 \mathrm{~h}$ on polylysine-coated coverslips in defined culture media (Agresti et al., 2005) plus PDGF and bFGF (10 $\mathrm{ng} / \mathrm{ml}$ ) (Preprotech).

\section{Slice preparation}

Time-lapse image acquisitions of green fluorescent protein (GFP)labeled living OPCs were performed on slices cut in coronal and sagittal orientation between postnatal days 2 and 8 (P2-P8), as described previously (Kakita and Goldman, 1999). Briefly, mice were anesthetized with isoflurane, after which brains were rapidly removed and stored in ice- cold bicarbonate buffered solution gassed with $95 \% \mathrm{O}_{2}$ and $5 \% \mathrm{CO}_{2}$. Coronal and sagittal slices were cut at $300 \mu \mathrm{m}$ thickness on a Vibratome. Brain slices were first collected in ice-cold bicarbonate solution, after which they were incubated in the same bicarbonate solution at $30^{\circ} \mathrm{C}$ for $30 \mathrm{~min}$. The slices were then cultured with Eagle's Basal Medium with Earle's salts (BME; Invitrogen) supplemented with $18.6 \mathrm{~mm} \mathrm{NaHCO}_{3}$, $1 \%$ BSA (fraction 5; Sigma), $5 \mu \mathrm{g} / \mathrm{ml}$ insulin, $5 \mu \mathrm{g} / \mathrm{ml}$ transferrin, 5 $\mu \mathrm{g} / \mathrm{ml}$ sodium selenite (Sigma), $20 \mathrm{U} / \mathrm{ml}$ penicillin-streptomycin (Invitrogen), $2 \mathrm{~mm}$ L-glutamine (Invitrogen), $27 \mathrm{~mm}$ glucose, $7.9 \mathrm{~mm} \mathrm{NaCl}$ plus PDGF and bFGF (20 ng/ml) (Peprotech). After that, brain slices were ready for time-lapse video microscopy studies.

\section{Time-lapse image acquisition}

Cultured OPCs or brain slices were incubated in a stage top chamber with $5 \% \mathrm{CO}_{2}$ at $37^{\circ} \mathrm{C}$ (Live-Cell Control Unit), which was placed on the stage of a Olympus spinning disc confocal inverted microscope equipped with a motorized $\mathrm{z}$-stage. A $20 \times$ objective was used for acquiring images. Bright-field images were acquired for primary cultures of cortical OPCs, whereas fluorescent field images were obtained for brain slices with a specific GFP filter at $0.5 \mathrm{~ms}$ exposure times. Images were taken every 6 min over a period of $4-24 \mathrm{~h}$ using a CCD camera (Hamamatsu ORCAER) and a Image analysis software (SlideBook 4.1, Intelligent Imaging Innovations). Cell migration speed and distances were analyzed off-line by tracing individual cells using the motion tracking function of SlideBook software. The brightest part of each cell body was used as the tracking target. For GFP-labeled OPCs in living slices tracking was started from a time point when a cell first came into focus or appeared at the edge of the imaging field until it either went out of focus or left the imaging field. Subsequently, migratory values were statistically analyzed across genotypes. Data are presented as mean \pm SEM. Statistical significance was assessed by using the Student paired $t$ test, in which $p<0.05$ was defined as statistically significant.

\section{Transwell migration assay}

A three-dimensional cell migration assay was performed with the Transwell system, which allows cells to migrate through an $8 \mu \mathrm{m}$ pore size polycarbonate membrane. Enriched oligodendrocytes from control, golli KO and JOE mice were prepared as described by Amur-Umarjee et al. (1993). After 9 d, OPCs were purified from the mixed glial culture by the differential shaking and adhesion procedure by Suzumura et al. (1984) and cells were resuspended in DMEM/F-12 containing 10\% FBS $\left(1 \times 10^{6} \mathrm{cells} / \mathrm{ml}\right)$. This suspension $(100 \mu \mathrm{l})$ was added to the upper chamber of the Transwell. The lower chamber was filled with $600 \mu \mathrm{l}$ of defined culture media (Agresti et al., 2005) plus PDGF $(20 \mathrm{ng} / \mathrm{ml})$. Then the DMEM/F-12 medium containing 10\% FBS in the upper chamber was replaced with serum-free DMEM/F-12. After incubation during different periods of time at $37^{\circ} \mathrm{C}$ in the presence of $5 \% \mathrm{CO}_{2}$, the cells were fixed for $30 \mathrm{~min}$ in $4 \%$ paraformaldehyde and stained for $10 \mathrm{~min}$ with DAPI. The filters were then rinsed thoroughly in distilled water and checked by bright-field microscopy to ensure that the cells were adherent and had migrated. The nonmigrating cells were then carefully removed from the upper surface (inside) of the Transwell with a wet cotton swab. To quantify cell motility, cells that had migrated to the bottom surface of the filter were counted. Counting of cells in these experiments was facilitated by use of OPCs isolated from control, golli KO and JOE mice that were bred onto a background in which OPCs are tagged with GFP. Nine evenly spaced fields of cells were counted in each well, using an inverted phasecontrast microscope at $20 \times$ magnification. Data are presented as mean \pm SEM. Statistical significance was assessed by using the Student paired $t$ test, in which $p<0.05$ was defined as statistically significant.

\section{Construction of the GFP clones}

The construction of the full-length J37 and BG21 clones in pEGFP-N3 was described by Reyes and Campagnoni (2002). J37 deletion 1 and 2 were constructed by amplifying portions of 337 cDNA in pGEM-3Zf ${ }^{-}$ using a common $3^{\prime}$ primer: TGAATTCTTGGTACCGCGTCTCGCCATGGGAGA and the following 5'primers: CAATTAGCTAGCGAATTCAATGGTGTTTGGGGAGGCAGA (Del1) and CATTAGCTAGCGAATTCAATGGACAGGCCCTCAGAGTC (Del2). DNA insert amplification was performed in accordance with the manufacturer's 
recommendations (Invitrogen). The cycling conditions were as follows: (1) $5 \mathrm{~min}$ at $95^{\circ} \mathrm{C}$ for $1 \mathrm{cycle}$; (2) $3 \mathrm{~min}$ at $95^{\circ} \mathrm{C}, 2 \mathrm{~min}$ at $68^{\circ} \mathrm{C}, 2 \mathrm{~min}$ at $72^{\circ} \mathrm{C}$ for 30 cycles. The product was digested with EcoRI-KpnI and inserted into pEGFP-N3 in frame with the green fluorescent protein.

The myristoylation mutations were made by site-directed mutagenesis (Clontech) using the J37 and BG21 EGFP clones and the following oligonucleotide: 5'-GCTCAAGCTTCGAATTCATGGCCAACCACTCTGG-3'; the selection marker was a BglII to ScaI mutation. This clone was transferred to pEGFP-N3 using the same PCR primers as J37.

\section{Cell line preparation and transfection}

The N19 conditionally immortalized cell line (Verity et al., 1993) was grown in DMEM and Ham's F12 (1:1 v/v) (Invitrogen), containing 100 $\mu \mathrm{g} / \mathrm{ml}$ gentamicin and $100 \mu \mathrm{g} / \mathrm{ml} \mathrm{G} 418$ sulfate (Omega Scientific), supplemented with $4 \mathrm{mg} / \mathrm{ml}$ dextrose anhydrous, $3.75 \mathrm{mg} / \mathrm{ml} \mathrm{HEPES} \mathrm{buffer,}$ $2.4 \mathrm{mg} / \mathrm{ml}$ sodium bicarbonate and $10 \%$ fetal bovine serum (FBS) (Omega Scientific). Cultures were maintained at $34^{\circ} \mathrm{C}$ with $5 \% \mathrm{CO}_{2}$. Cells plated onto poly-D-lysine-coated $12 \mathrm{~mm}$ glass coverslips were transfected using the Lipofectamine 2000 (Invitrogen). Briefly, $1 \mu \mathrm{g}$ of plasmid DNA was used to transfect $4.5 \times 10^{4}$ cells/coverslip. While the DNA was complexing, the cells were washed for $5 \mathrm{~min}$ with serum free media. The complexed DNA mixture was then applied to the coverslips and incubated at $34^{\circ} \mathrm{C}$ for $6 \mathrm{~h}$. The samples were washed with media supplemented with $10 \% \mathrm{FBS}$ and subsequently incubated at $39^{\circ} \mathrm{C}$ for $2 \mathrm{~d}$ before the migration assay.

\section{Agarose drop assay}

Analysis of the migration of N19 cell line out an agarose drop containing a large concentration of cells, was performed following the technique of Varani et al. (1978) and Milner et al. (1997), modified by Simpson and Armstrong (1999). Briefly, N19 cells were centrifuged at 1500rpm for 10 min and resuspended in a small volume of DMEM/F12 containing $10 \%$ FBS and $0.3 \%$ low melting point agarose (kept at $37^{\circ} \mathrm{C}$ ), to achieve a final concentration of approximately $50 \times 10^{6} \mathrm{cells} / \mathrm{ml}$. One microliter of this cell suspension was placed in each well and incubated at $4^{\circ} \mathrm{C}$ for $15 \mathrm{~min}$. One milliliter of prechilled DMEM/F12-10\% FBS containing PDGF (20 $\mathrm{ng} / \mathrm{ml}$ ) was then added to each well. The culture plates were placed in the tissue incubator and maintained at $37^{\circ} \mathrm{C}$. Cell movements out of the drop in each of four opposite directions were measured by time-lapse phase contrast microscopy over the course of $20 \mathrm{~h}$. All experiments were performed in at least triplicate wells. Cell migration speed and distances, in N19 control and overexpressing golli, were calculated for each experiment, and the results were expressed as mean \pm SEM. Statistical significance was assessed by using the Student paired $t$ test, in which $p<0.05$ was defined as statistically significant.

\section{Calcium imaging}

Calcium imaging experiments were performed using two different calcium indicators, Fluo-4 AM or Fura-2 AM Fluo-4 AM was used in all experiments of at least $1 \mathrm{~h}$ duration, mainly to evaluate qualitatively spontaneous $\mathrm{Ca}^{2+}$ activity in migrating cells. The dye Fura-2 was usually used in experiments of shorter duration (usually 20-40 $\mathrm{min}$ ) to estimate intracellular $\mathrm{Ca}^{2+}$ concentrations ratiometrically. Methods were similar to those described previously (Colwell, 2000; Michel et al., 2002; Paz Soldán et al., 2003). Briefly, a cooled CCD camera (Hamamatsu ORCAER) was added to the Olympus spinning disc confocal microscope to measure fluorescence. Cells were loaded for $30 \mathrm{~min}$ at $37^{\circ} \mathrm{C}$ with $0.5 \mu \mathrm{M}$ Fluo-4 AM (Invitrogen) and were transferred in a perfusion chamber (Bioscience Tools) connected to a microperfusion system. Experiments were performed at a chamber temperature of $37^{\circ} \mathrm{C}$. During experiments, cells were bathed in defined culture media (Agresti et al., 2005) plus PDGF and bFGF $(10 \mathrm{ng} / \mathrm{ml})$; in some experiments, the medium was completely exchanged for an identical one with added pharmacological agents by means of the peristaltic pump. Single-cell intracellular $\mathrm{Ca}^{2+}$ concentration measurements were performed exciting Fluo- 4 at $488 \mathrm{~nm}$ for $<200 \mathrm{~ms}$. The use of this protocol, together with the low dye loading concentration of $0.5 \mu \mathrm{M}$, allowed us to perform experiments without detectable morphological photodamage of migrating cells. Higher dye concentrations in fact impaired cell migration and viability, as well as their ability to generate spontaneous calcium signals. Fluorescence was determined from regions of interest (ROI) covering single-cell bodies. Dye excitation, image acquisitions and ROI analysis protocols were performed with Image analysis software (SlideBook 4.1, Intelligent Imaging Innovations). Estimations of fluorescence intensity were defined as the pseudoratio $\Delta F / F$ according to the following formula: $\Delta F / F=(F-F$ base) $/(F$ base $-B)$, where $F$ is the measured fluorescence intensity of the Fluo-4 indicator, $F$ base the fluorescence intensity of the indicator in the cell before stimulation, and $B$ the background signal from the averaged areas adjacent to the cell.

Calibration of $\mathrm{Ca}^{2+}$ signals

The dye Fura-2 AM (TefLabs) plus $0.08 \%$ Pluronic F-127 (Molecular Probes) was incubated with OPCs cultures for $30 \mathrm{~min}$ at $37^{\circ} \mathrm{C}$ at a final concentration of $4 \mu \mathrm{M}$. The fluorescence of Fura- 2 was excited alternatively at wavelengths of 340 and $380 \mathrm{~nm}$ by means of a high-speed wavelength-switching device (Lambda DG-4; Sutter Instruments). A microperfusion system was used to rapidly and locally perfuse solutions of different ionic composition. The intracellular $\mathrm{Ca}^{2+}$ concentration was estimated as follows.

Free $\left[\mathrm{Ca}^{2+}\right]$ was estimated from the ratio $(R)$ of fluorescence at 340 and $380 \mathrm{~nm}$, using the following equation: $\left[\mathrm{Ca}^{2+}\right]=K_{\mathrm{d}} \times$ slope factor $\times$ $\left(R-R_{\min }\right) /\left(R_{\max }-R\right)$ (Grynkiewicz et al., 1985). The $K_{\mathrm{d}}$ was assumed to be $140 \mathrm{nM}$, whereas values for $R_{\min }$ and $R_{\max }$ were all determined via calibration methods. An in vitro method (Fura2 $\mathrm{Ca}^{2+}$ imaging calibration kit, Molecular Probes) was used to estimate the values. With this method, glass coverslips were filled with a high-Ca ${ }^{2+}$ (Fura-2 plus $10 \mathrm{~mm}$ $\mathrm{Ca}^{2+}$ ), a low-Ca ${ }^{2+}$ (Fura-2 plus 10 mm EGTA), and a control solution without Fura-2. Each solution also contains a dilute suspension of $15 \mu \mathrm{m}$ polystyrene microspheres to ensure uniform coverslip/slide separation and facilitate microscope focusing. The fluorescence $(F)$ at $380 \mathrm{~nm}$ excitation of the low $\mathrm{Ca}^{2+}$ solution was imaged, and the exposure of the camera adjusted to maximize the signal. These camera settings were then fixed, and measurements were made with 380 and $340 \mathrm{~nm}$ excitation of the three solutions. $R_{\min }=F_{340 \mathrm{~nm}}$ in low $\mathrm{Ca}^{2+} / \mathrm{F} 380$ in low $\mathrm{Ca}^{2+} ; R_{\max }$ $=F_{340}$ in high $\mathrm{Ca}^{2+} / F_{380}$ in high $\mathrm{Ca}^{2+} ; S f=F_{380}$ in low $\mathrm{Ca}^{2+} / F_{380}$ in high $\mathrm{Ca}^{2+}$.

\section{Results}

\section{Golli modulates oligodendroglial cell migration in vitro}

Using time-lapse video microscopy we examined the effect of golli on OPC migration. These experiments were performed over a period of $24 \mathrm{~h}$ on OPCs isolated from control, KO, and JOE mice, in medium containing PDGF and bFGF $(10 \mathrm{ng} / \mathrm{ml})$. In this time-lapse two-dimensional cell migration assay, cell movement was assessed by calculating the average cell migration velocity and the total distance traveled by the cell. For this analysis, only OPCs moving $>50 \mu \mathrm{m}$ in $6 \mathrm{~h}$ were scored. Tracking of cells was performed using the SlideBook 4.1 data analysis program described by Materials and Methods. Migrating OPCs were automatically followed by tagging a color or number to each cell examined, which were then tracked from frame to frame. Examples of such measurements are shown in Figure $1 A$, in which four golli overexpressing cells are colored in green, red, yellow and blue. The easiest cell to track in this presentation is the green cell, which clearly moves a significant distance over the period examined. Movement of the other cells is less obvious but they were clearly measurable (see supplemental video 1, available at www.jneurosci.org as supplemental material). Under these experimental conditions the mean rate of migration for control and golli KO OPCs was $26 \pm 4.5 \mu \mathrm{m} / \mathrm{h}$ and $18 \pm 2.8 \mu \mathrm{m} / \mathrm{h}$, respectively, $p<0.01$ (Fig. $1 B$ ). So the average cell migration velocity in golli KO OPCs was significantly reduced compared with that of the control group. In similar experiments the average cell velocity in golli overexpressing cells (JOE) was found to be almost double that of the JOE control cells $(48 \pm 4.1 \mu \mathrm{m} / \mathrm{h}$ and $23 \pm 3.7 \mu \mathrm{m} / \mathrm{h}$, respectively, $p<0.01$ ) (Fig. $1 B$ ). As might be expected, there was an increase in the total migration distance (Fig. 

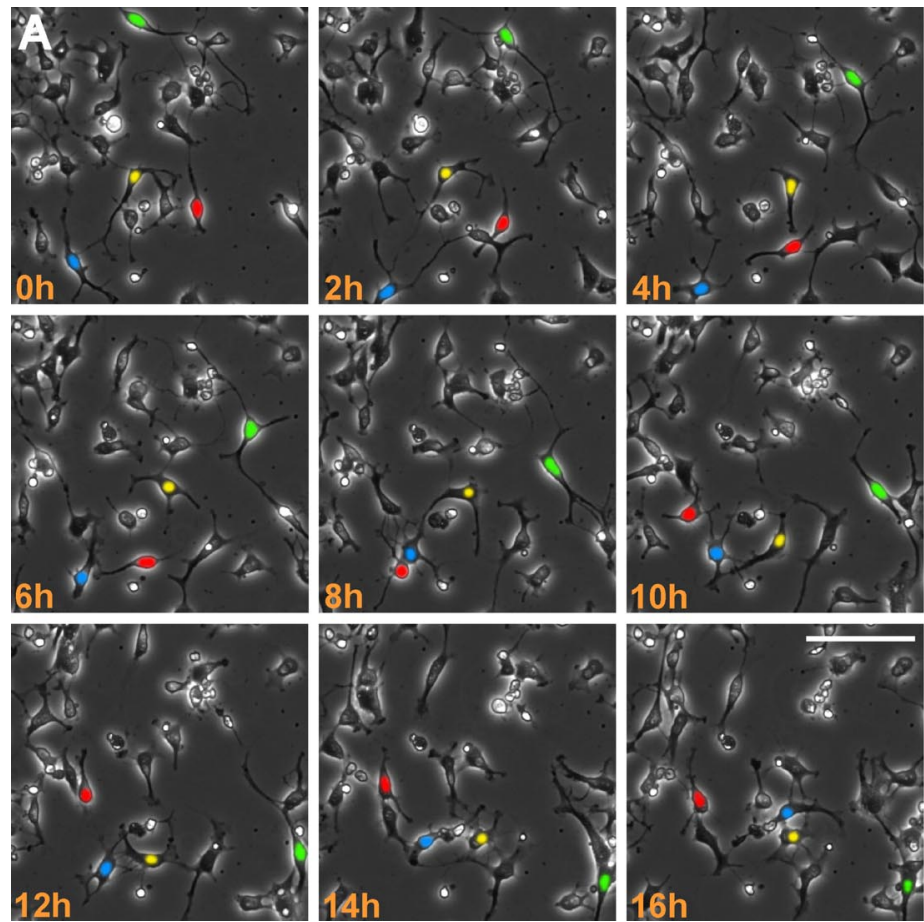

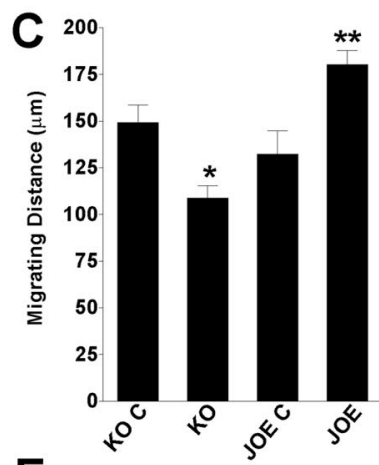

E

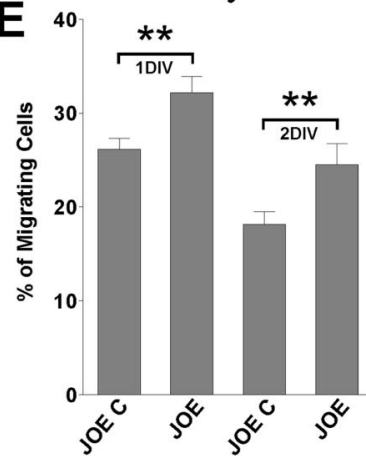

Figure 1. Overexpression of Golli enhances $O P C$ migration. Cultured $O P C s$ were incubated in a stage top chamber with $5 \% \mathrm{CO}_{2}$ at $37^{\circ} \mathrm{C}$, which was placed on the stage of a spinning disc confocal inverted microscope. $\boldsymbol{A}$, Bright-field images were acquired at 6 min intervals for a total of $24 \mathrm{~h}$. Cell migration speed and distances were analyzed off-line by tracing individual cells at different times, after which migratory values were statistically analyzed across genotypes. B, OPC average migration speed was calculated from at least 60 cells in each experimental condition. $\boldsymbol{C}$, Total migration distance was followed for $12 \mathrm{~h}$ in 50 cells from each genotype. $\boldsymbol{D}, \boldsymbol{E}$, The percentage of migrating cells (cells moving $>50 \mu \mathrm{m}$ in $6 \mathrm{~h}$ ) was calculated from the entire cell population. Values are expressed as mean \pm SEM of at least four independent experiments. ${ }^{*} p<0.05,{ }^{* *} p<0.01,{ }^{* *} p<0.001$ versus control cells. Scale bar, $40 \mu \mathrm{m}$.
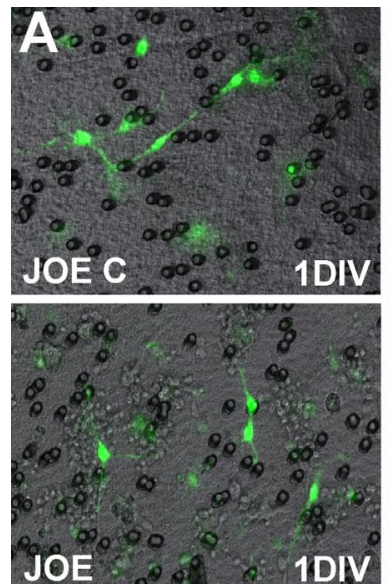
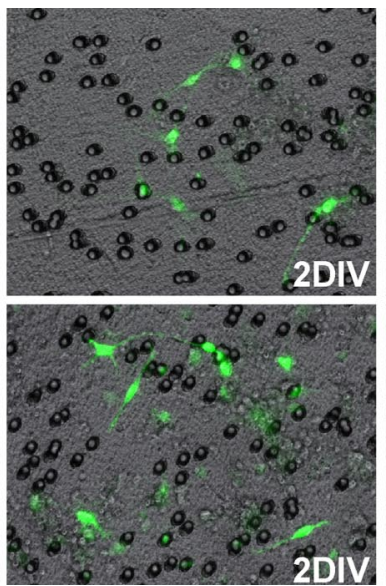
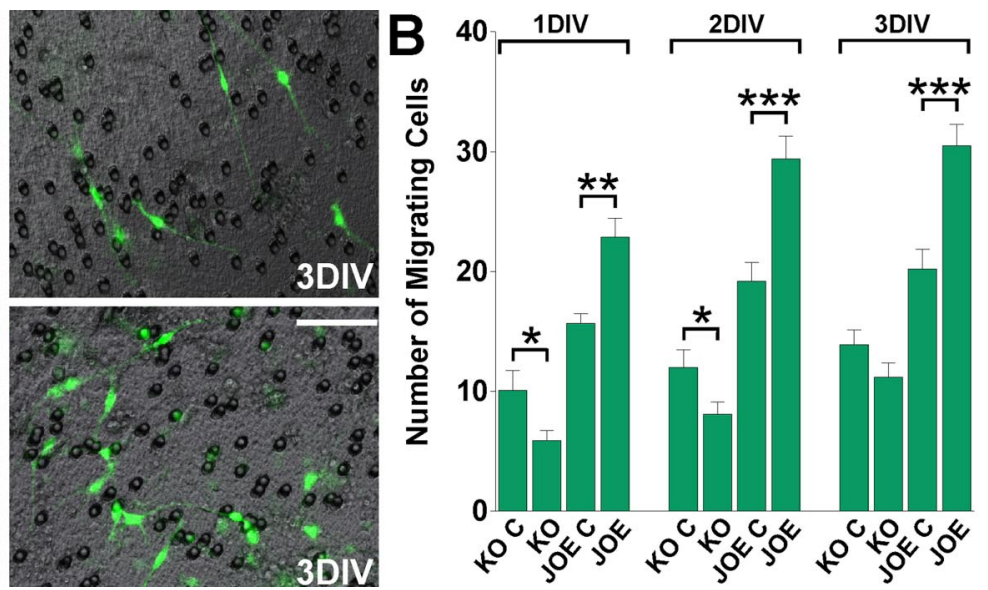

Figure 2. Golli promotes in vitro oligodendroglial cell motility. A cell migration assay was performed with the Transwell system, which allows cells to migrate through an $8 \mu \mathrm{m}$ pore size polycarbonate membrane. Each microchemotaxis assay allowed a 1-3 d period for migration. Triplicate wells with control cells were run simultaneously in the same chamber set as the triplicate wells of golli KO and JOE cells. Counting of cells in these experiments was facilitated by use of OPCs isolated from control, golli KO and JOE mice that were bred onto a background in which OPCs are tagged with GFP. A, Morphology of migrating JOE OPCs after different times points in the microchemotaxis assay. The cells are mostly bipolar with processes that are expanded. $\boldsymbol{B}$, To quantify cell motility after 1, 2, and 3 DIV, cells that had migrated to the bottom surface of the filter were counted. Five evenly spaced fields of cells were counted in each well, using an inverted fluorescent microscope at $20 \times$ magnification. Values are expressed as mean \pm SEM of at least four independent experiments. ${ }^{*} p<0.05,{ }^{* *} p<0.01,{ }^{* * *} p<0.001$ versus control cells. Scale bar, $40 \mu \mathrm{m}$.

$1 C)$, and we also found an increase in the number of migrating cells (cells moving $>50 \mu \mathrm{m}$ in $6 \mathrm{~h}$ ) in the JOE OPC population (Fig. $1 D, E)$.

Further analysis of cell migration was performed using the Transwell system, which provides a three-dimensional assessment of motility. Counting of cells in these experiments was facilitated by use of OPCs isolated from golli $\mathrm{KO}$ and JOE mice that were bred onto a background in which OPCs are tagged with GFP (Mallon et al., 2002). OPCs were plated on one side of the mem- brane and migrating, fluorescently tagged cells were counted on the other side of the membrane after $24 \mathrm{~h}$ [ 1 day in vitro (DIV)], $48 \mathrm{~h}$ (2 DIV), and $72 \mathrm{~h}$ (3 DIV). In the presence of PDGF (20 $\mathrm{ng} / \mathrm{ml}$ ) the fluorescently labeled JOE cells were found to migrate faster than the control cells in this assay (Fig. 2). Conversely, golli-deficient OPCs were observed to migrate slower than control OPCs (Fig. 2). These findings are in good agreement with the direct measurement of velocity made in cultured OPCs. Overall, the data showed increased cell migration velocity and total mi- 

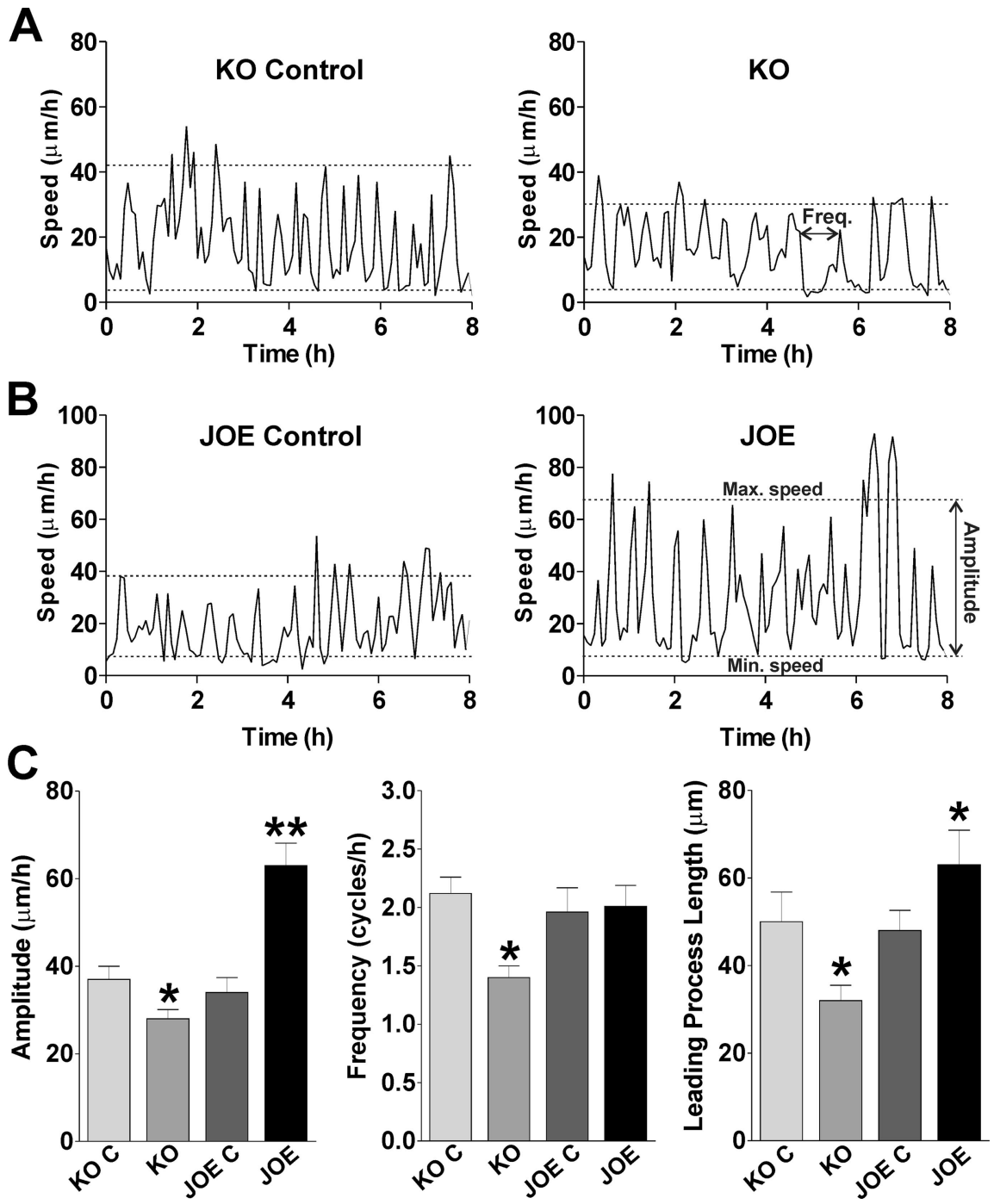

Figure 3. Migrating cells move in a saltatory manner. $\boldsymbol{A}, \boldsymbol{B}$, Four examples of the saltatory movement of migrating $0 \mathrm{PC}(\mathrm{s}$ during $8 \mathrm{~h}$ from golli KO, JOE and the corresponding control cells are shown. C, Average amplitude and frequency of saltatory behavior and leading process length of migrating $\mathrm{OPCs}$. Values are expressed as mean \pm SEM of at least four independent experiments. ${ }^{*} p<$ $0.05,{ }^{* *} p<0.01$, versus control cells.

gration distance as well as increased numbers of migrating cells in the JOE population.

Migrating cells move in a saltatory manner, alternating periods of higher and lower speed at a frequency of $\sim 1-2$ cycles $/ \mathrm{h}$. These cycles reflect the steps requires for directed OPC movement: extension of the leading process, translocation of the soma/ nucleus (nucleokinesis), and retraction of the trailing process, these three individual steps constitute a single migration cycle (saltatory movement). We measured the average frequency and amplitude of saltatory movement of OPCs migrating in our culture system, and examples of this in control, KO and JOE OPCs are shown in Figure $3 A, B$. We found a significant decrease in the frequency of saltatory oscillations in KO OPCs compared with control cells $(1.41 \pm 0.20 \mathrm{cycles} / \mathrm{h}$, and $2.12 \pm 0.14 \mathrm{cycles} / \mathrm{h}$, respectively, $n=25 p<0.05$ ) (Fig. $3 C$ ). Additionally, the average maximum speed in KO OPCs was significantly lower than the average maximum speed in control cells $(32 \pm 3.1 \mu \mathrm{m} / \mathrm{h}$ and $41 \pm 3.0 \mu \mathrm{m} / \mathrm{h}$, respectively, $n=20 p<0.05)$. These data suggest that the average speed changes in golli $\mathrm{KO}$ cells are due to a reduction in the maximum speed reached during the soma trans- location together with an increase in the duration of resting phases of migration.

There was no difference between the frequency of these saltatory oscillations in JOE control and JOE cells $(1.96 \pm 0.21$ cycles/h, and $2.01 \pm 0.18$ cycles/h, respectively, $n=25$ ) (Fig. 3C). However, the average maximum speed in JOE OPCs was significantly higher than in the JOE control cells $(67 \pm 5.1 \mu \mathrm{m} / \mathrm{h}$, and $38 \pm 3.4$ $\mu \mathrm{m} / \mathrm{h}$, respectively, $n=25 p<0.01$ ) (Fig. $3 B)$. These data indicate that the amplitude of saltatory oscillations (difference between maximum and minimum speeds during nucleokinesis), but not the resting times between cycles (frequency), is responsible for the greater migration rates of the JOE OPCs.

Using high resolution spatiotemporal microscopy, we determined the average length of individual leading processes in migrating OPCs before the initiation of the migration cycle (before nucleokinesis). We found that the average leading process was significant longer in JOE cells and significantly shorter in $\mathrm{KO}$ OPCs than in corresponding control cells, demonstrating that during OPC migration golli overexpression promotes leading process extension (Fig. $3 C$ ). Together these experiments localized the step in the migration process in which golli plays a role and suggest that golli modulates OPC migration by accelerating both nucleokinesis and leading process growth. Faster nucleokinesis could be responsible for the higher amplitude (difference between lowest and highest speed) found in JOE cells and slow leading process formation could be responsible for the increase in the resting time between cycles of advancement in golli KO OPCs.

Spontaneous $\mathrm{Ca}^{2+}$ oscillations modulate OPC migration We tested the possibility that the observed effects on OPC migration were due to the effects of golli on $\mathrm{Ca}^{2+}$ uptake by performing live imaging experiments to examine and correlate cell mobility with intracellular $\mathrm{Ca}^{2+}$ changes in primary cultures of OPCs isolated from golli $\mathrm{KO}$ and JOE mice. The combined use of real time confocal microscopy and $\mathrm{Ca}^{2+}$ indicator dye (Fluo-4) reveals that OPCs exhibit transient $\mathrm{Ca}^{2+}$ elevations as they migrate in vitro (Fig. $4 A$; supplemental video 2 , available at www.jneurosci.org as supplemental material). The frequency and amplitude of $\mathrm{Ca}^{2+}$ transients in the OPC somata changes dynamically during their migration (supplemental Fig. 1, available at www.jneurosci.org as supplemental material; Fig. $4 B$ ) and it correlates positively with the rate of cell movement (correlation coefficient, $0.91 r^{2}$ ). Interestingly, golli overexpression was associated with a significant increase in the mean $\mathrm{Ca}^{2+}$ oscillation amplitude from $87.2 \pm 2.2 \mathrm{nM}$ in control cells to $117.2 \pm 3.1 \mathrm{nM}(p<0.01)$ in JOE cells (Fig. $5 A)$, an effect that is reflected in the rightward shift in the frequency distribution of spontaneous events in JOE versus JOE control OPCs shown in Figure 5C. 

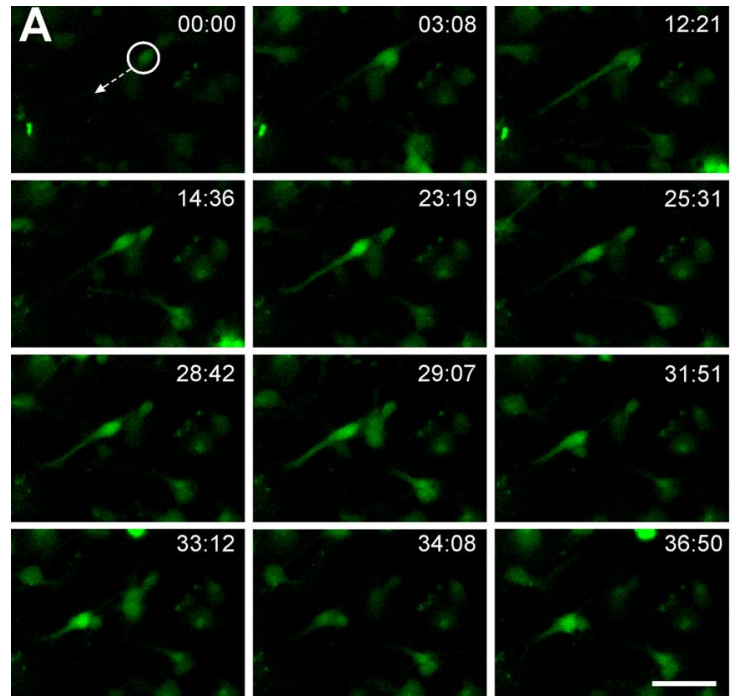
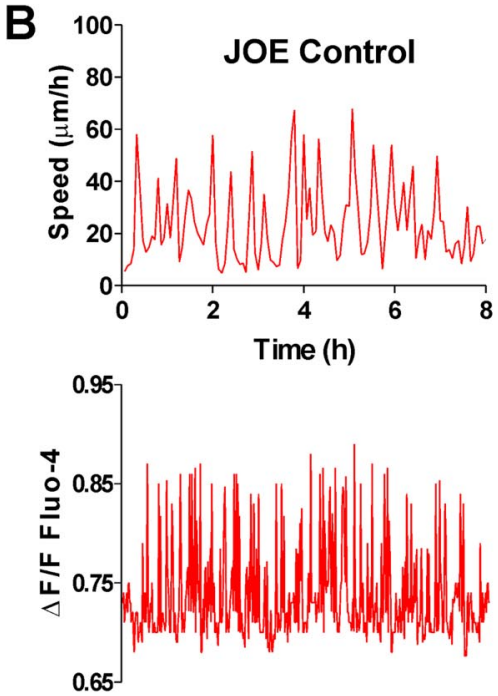
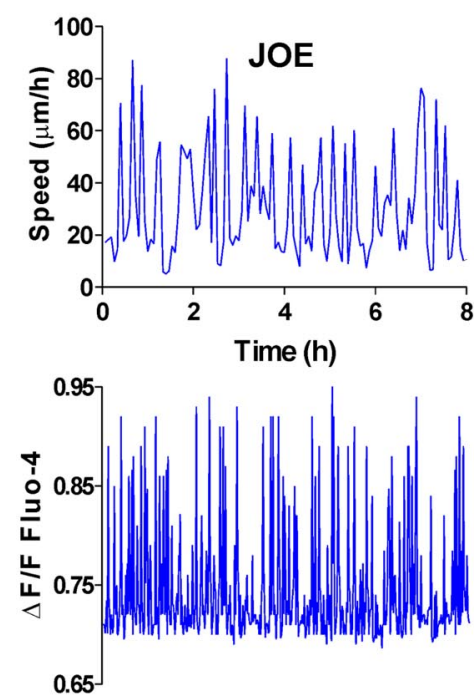

Figure 4. Spontaneous $\mathrm{Ca}^{2+}$ transients in migrating OPCs. $\boldsymbol{A}$, Time-lapse images showing a typical example of a migrating JOE OPC displaying transient elevations of the $\left[\mathrm{Ca}^{2+}\right]_{\text {int }}$ level in its soma and leading process. Elapsed time (minutes and seconds) is indicated on the top of each image. Scale bars, $25 \mu \mathrm{m}$. $\boldsymbol{B}$, Analysis of saltatory oscillations in control and JOE OPCs and sequential changes in the $\mathrm{Ca}^{2+}$ transients over time in the same cells. Upward deflections in lines represent elevations of the intracellular $\mathrm{Ca}^{2+}$ levels in the OPCs somata and downward deflections indicate decreases of $\mathrm{Ca}^{2+}$ levels.

This increase in amplitude of spontaneous $\mathrm{Ca}^{2+}$ events could be caused by the addition of a few very large events or a shift in the size of all events. To investigate these two possibilities, we constructed cumulative probability histograms of spontaneous $\mathrm{Ca}^{2+}$ oscillations amplitudes from JOE control and golli-overexpressing OPCs (Fig. $5 E$ ). These two distributions were found to be significantly different (Kolmogorov-Smirnov test, $p<0.001$ ). The cumulative probability shown in Figure $5 E$ is an average cumulative probability \pm SEM from 18 cells for each genotype. Beginning at the third bin (30 nM), the two cumulative probabilities are significantly different in each bin by the $t$ test $(p<0.05)$. This analysis suggests that the entire population of events is increased in size, with the median increasing by $\sim 35 \%$. However, the absence of golli was associated with a significant decrease in the mean $\mathrm{Ca}^{2+}$ oscillation amplitude from $93.5 \pm 3.1 \mathrm{nM}$ in control cells to $58.7 \pm 4.0 \mathrm{nM}(p<0.01)$ (Fig. $5 B)$, an effect that is reflected in the leftward shift in the frequency distribution of $\mathrm{Ca}^{2+}$ oscillations in $\mathrm{KO}$ versus control OPCs (Fig. 5D). The cumulative probability histogram suggests that the entire population of events is decreased in size by $\sim 37 \%$. (Fig. $5 F$ ). No significant differences were observed in the mean $\mathrm{Ca}^{2+}$ oscillation frequency in any of the cell populations studied (data not shown). These results reveal a modulation of the amplitude of spontaneous $\mathrm{Ca}^{2+}$ oscillations in golli $\mathrm{KO}$ and JOE cells, which is likely to be one of the factors involved in the alterations in OPC migration that we observed in cells lacking and overexpressing golli.

\section{Golli proteins play a role in modulating OPC migration through VOCCs}

It was shown previously that golli proteins play a key role in the modulation of voltage-dependent $\mathrm{Ca}^{2+}$ influx in OPCs (Paez et al., 2007) and recent studies suggest that VOCCs generate $\mathrm{Ca}^{2+}$ signals that play a vital role in the migration of cerebellar granule cells (Komuro and Rakic, 1992, 1998). For this reason, we examined the role played by VOCCs on OPC migration by performing several combined $\mathrm{Ca}^{2+}$ imaging/cell migration experiments in the presence of pharmacological agents to stimulate or inhibit voltage-gated $\mathrm{Ca}^{2+}$ uptake in OPCs. First, we examined the effect of lowering extracellular $\mathrm{Ca}^{2+}$ levels through chelation with EGTA or by reducing the $\left[\mathrm{Ca}^{2+}\right]$ in the medium. Second, we assessed the effect of specific L-type VOCC blockers such as nifedipine and verapamil. These treatments resulted in a significant reduction in the $\mathrm{Ca}^{2+}$ transient frequency and amplitude and a slowdown of OPC movement (Fig. 6), indicating that VOCCs, known to contribute to homeostatic $\mathrm{Ca}^{2+}$ balance in OPCs and other cells, are important in modulating OPC migration. Of considerable interest, is that stimulation of $\mathrm{Ca}^{2+}$ influx through the voltage-gated $\mathrm{Ca}^{2+}$ channels (through high $\mathrm{K}^{+}$treatment) significantly increased the $\mathrm{Ca}^{2+}$ transient frequency and amplitude and accelerated cell movement (Fig. 6). Similar results were found using Bay K 8644, an L-type $\mathrm{Ca}^{2+}$ channel agonist which prolongs single channel open time without affecting the close time (Fig. 6). These data show that changes in $\mathrm{Ca}^{2+}$ transients resulting from the modulation of voltage-gated $\mathrm{Ca}^{2+}$ influx provide a powerful means by which OPC migration may be regulated in vitro. These results also demonstrate that OPC movement is related to the frequency and amplitude of $\mathrm{Ca}^{2+}$ transients in OPC somata, and that $\mathrm{Ca}^{2+}$ transient frequency and amplitude provides an intracellular signal for controlling the rate of OPC migration.

The above results show that spontaneous $\mathrm{Ca}^{2+}$ oscillations in OLs are generated in response to voltage-dependent calcium channel activation. To investigate their role in golli-dependent modulation of migration velocity we tracked control and gollioverexpressing OPCs in medium containing the VOCC antagonist verapamil. Figure 7 shows that the average speed of OPC migration was lower in both JOE control and JOE OPCs when verapamil was present in the media. For example, in control media (Basal), the maximum average migration speed of JOE cells, was $67 \pm 5.1 \mu \mathrm{m} / \mathrm{h}(n=28)$, but as the concentration of verapamil was increased, it fell to an average speed of $32 \pm 2.6 \mu \mathrm{m} / \mathrm{h}$ $(n=25)$ in the presence of $10 \mu \mathrm{M}$ verapamil (Fig. $7 A)$. In $20 \mu \mathrm{M}$ verapamil there was essentially complete inhibition of JOE cell migration (Fig. $7 \mathrm{~A}, \mathrm{C}$ ). In the same migrating cells, this treatment also resulted in a significant reduction in the $\mathrm{Ca}^{2+}$ transient amplitude and frequency (Fig. $7 B$ ). Similar results were found using nifedipine, another specific L-type VOCC blocker (Fig. 7C).

In contrast, addition of high $\mathrm{K}^{+}$to the medium, a manipulation that activates VOCCs by depolarizing the plasma membrane, 

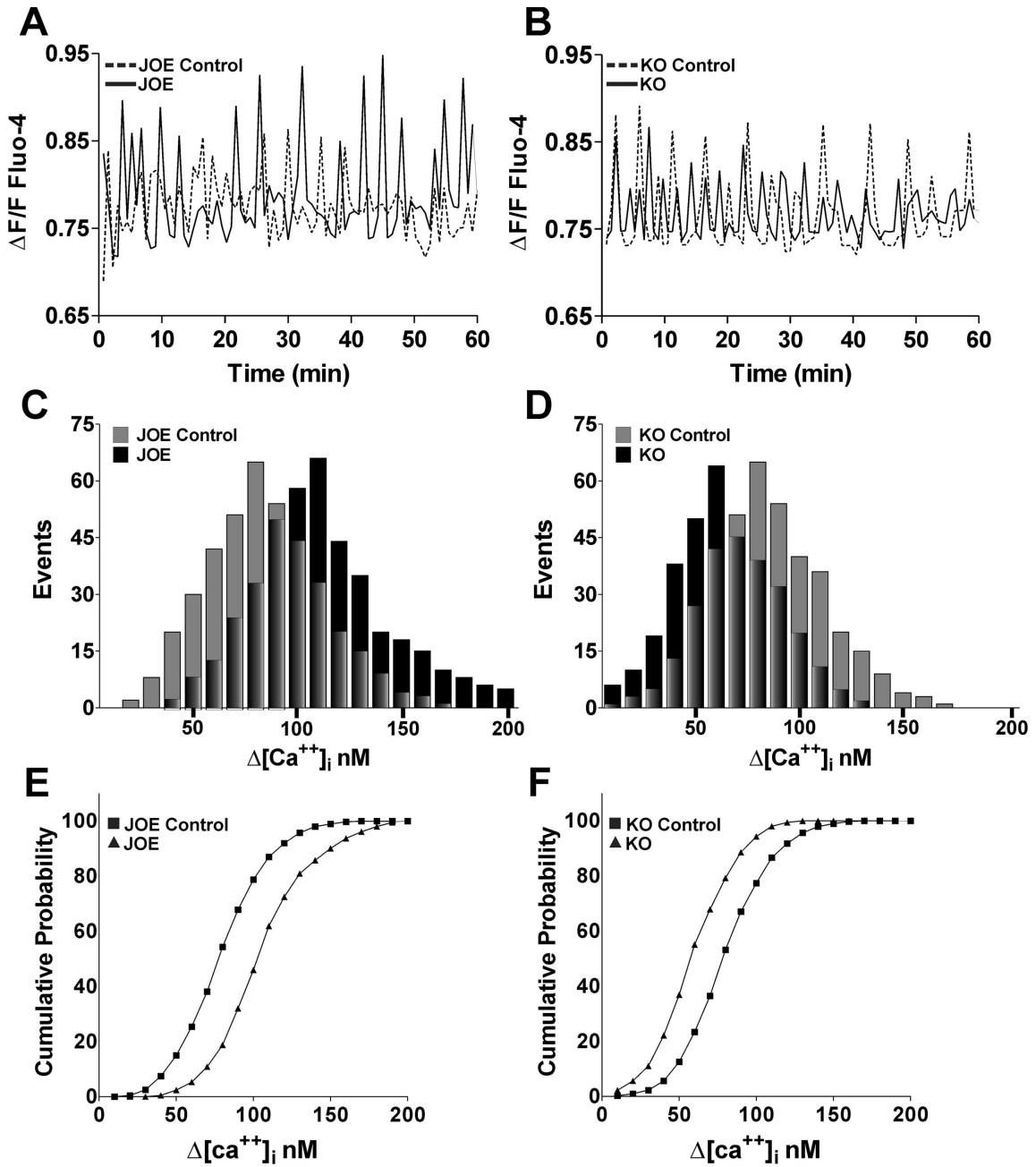

Figure 5. Golli stimulates the amplitude of $\mathrm{Ca}^{2+}$ oscillation in oligodendroglial cells. $\boldsymbol{A}, \boldsymbol{B}$, Representative recordings of spontaneous $\mathrm{Ca}^{2+}$ transients obtained from golli KO and JOE OPCS bathed in control medium are shown. $\boldsymbol{C}, \boldsymbol{D}$, Amplitude distribution histograms for spontaneous $\mathrm{Ca}^{2+}$ transients in golli KO, JOE, and the corresponding control cells during $1 \mathrm{~h}$ ( $n=18$ cells for each experimental condition). $\boldsymbol{E}, \boldsymbol{F}$, Cumulative probability histogram of measured spontaneous $\mathrm{Ca}^{2+}$ transient amplitudes from golli $\mathrm{KO}, \mathrm{JOE}$, and the corresponding control OPCS.

there was an increase in the average cell velocity (Fig. $8 \mathrm{~A}$ ) as well as the amplitude of $\mathrm{Ca}^{2+}$ transient in control and golli overexpressing cells (Fig. $8 \mathrm{~B}$ ). In basal conditions, JOE cells migrated at an average rate of $48 \mu \mathrm{m} / \mathrm{h}$ with an average $\mathrm{Ca}^{2+}$ transient amplitude of $117.2 \mathrm{~nm}$. In the presence of $15 \mathrm{~mm} \mathrm{~K}^{+}$, JOE OPCs migrated at a significantly higher rate of $74 \mu \mathrm{m} / \mathrm{h}$ with an increased $\mathrm{Ca}^{2+}$ transient amplitude of $128.4 \mathrm{nM}$. Thus, high $\mathrm{K}^{+}$ increased the rate of cell movement in JOE OPCs, along with increasing the amplitude of $\mathrm{Ca}^{2+}$ transients. Importantly, under this experimental condition (high $\mathrm{K}^{+}$), the migration speed and the amplitude of $\mathrm{Ca}^{2+}$ transients observed in migrating JOE cells were significantly higher than those observed in control OPC (Fig. 8A-C). Furthermore, potassium and golli-mediated modulation of OPC velocity disappeared when the VOCC antagonist verapamil was added to the external medium (Fig. $8 C$ ). These results clearly indicate that the golli-induced acceleration of OPC movement may result from an increase in the amplitude of $\mathrm{Ca}^{2+}$ transients generated by VOCCs.

In parallel time-lapse experiments, the effect of VOCCs inhibitors and high $\mathrm{K}^{+}$was evaluated in migrating OPCs obtained from golli $\mathrm{KO}$ and control mice. As expected, we found a significant decrease in the average speed and in the amplitude of $\mathrm{Ca}^{2+}$ transient induced by high $\mathrm{K}^{+}$in $\mathrm{KO}$ cells versus control OPCs (Fig. 8D). Additionally, the effect of golli ablation on OPC velocity disappeared when the VOCC antagonists verapamil and nifedipine were added to the medium (Figs. 7D, 8D). Changes in the frequency and amplitude of saltatory movements and $\mathrm{Ca}^{2+}$ transients in golli $\mathrm{KO}$ and overexpressing OPCs are summarize in Table 1.

Perturbations of golli structure exert similar effects on OPC migration and $\mathrm{Ca}^{2+}$ uptake

In mouse, three golli products have been identified: BG21, J37, and TP8 (Campagnoni et al., 1993). To identify any motifs on the golli protein that might be important in the effects of golli on OPC migration we prepared mutated/deleted versions of J37 and BG21 fused to GFP. The GFP-mutated golli plasmids were transfected into the immature oligodendroglial cell line N19 (Verity et al., 1993) and cell migration measured to define sites on the molecule that might be important in golli regulation of OPC migration. Figure $9 A$ diagrams the mutations/deletions used for analysis. Using the agarose drop migration assay we found that elimination of the first 45 or 110 amino acids from the $\mathrm{N}$ terminus of J37 (J37 Del1 and J37 Del2 respectively) completely obliterated the average cell velocity increase in the golli overexpressing cells (Fig. 9B,E). Previously, Feng et al. (2006) found that myristoylation of golli BG21 was important for targeting golli to the plasma membrane of Jurkat T-cells, and we found that mutation of the myristoylation sites of either golli J37 or BG21 (J37 and BG21 Myr) completely reversed the effects of golli on $\mathrm{Ca}^{2+}$ uptake in N19 cell line (Fig. 9C), indicating that membrane association is essential for golli action on the enhancement of $\mathrm{Ca}^{2+}$ influx in OPCs (Paez et al., 2007). As shown in Figure $9 B, D$, and $E$, myristoylation of golli and, indeed the first $110 \mathrm{~N}$-terminal amino acids, are essential for golli effects on cell migration, adding further evidence implicating a clear relationship between golli, $\mathrm{Ca}^{2+}$ uptake and OPC migration.

\section{Migration of subventricular zone OPCs is enhanced in golli overexpressing mice}

We tested whether increased levels of golli enhanced OPC migration in vivo by time-lapse imaging of live tissue sections containing GFP-labeled OPCs in golli KO and JOE mice. These experiments were performed using a double transgenic mouse created by breeding the golli $\mathrm{KO}$ and JOE mice with a line expressing GFP under control of the PLP promoter (Mallon et al., 2002). In these mice GFP expression provided a convenient marker for cells in the oligodendroglial lineage, thus facilitating the imaging experiments. We performed our in vivo measurements of OPC migration in slice preparations containing the lateral ventricle subventricular zone (SVZ) and corpus callosum since these regions have 
A
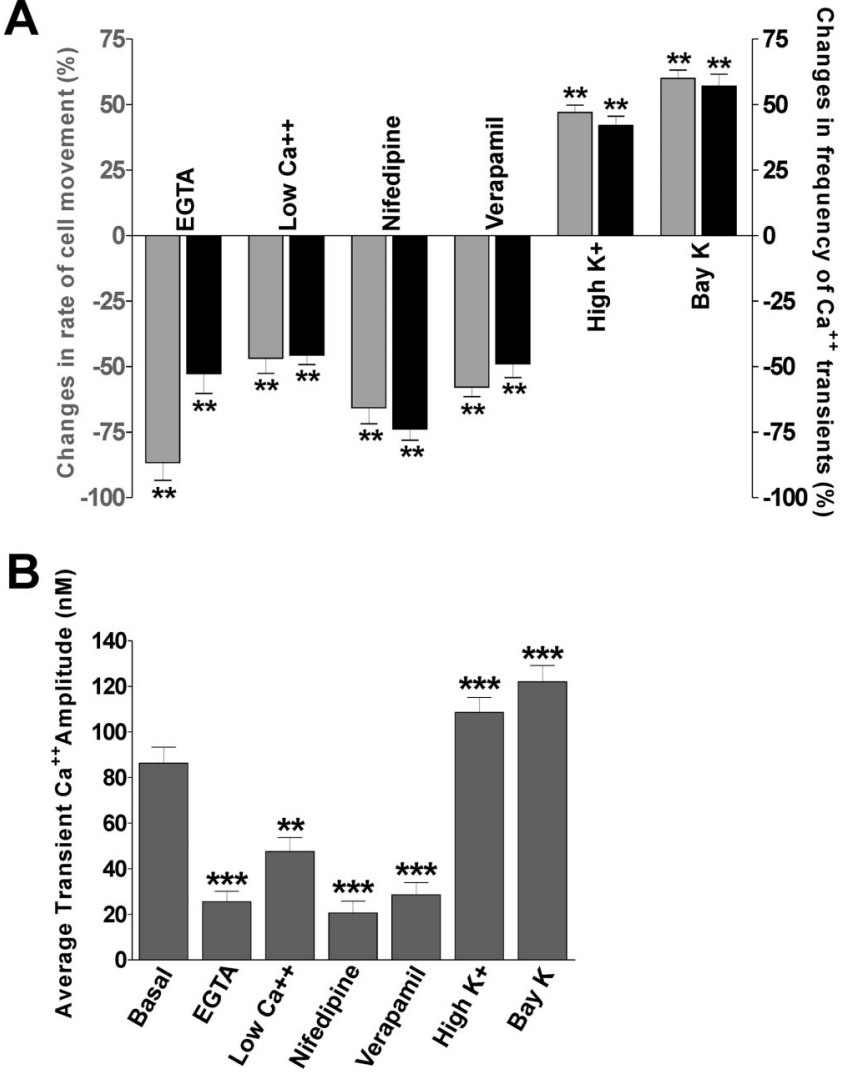

Figure 6. Effects of the changes in the $\mathrm{Ca}^{2+}$ transient frequency and amplitude on migrating oligodendroglial cells. A, EGTA (1 mM), nifedipine $(20 \mu \mathrm{M})$, verapamil $(20 \mu \mathrm{M})$, high $\mathrm{K}^{+}(15$ $\mathrm{mm})$, and BayK $(5 \mu \mathrm{M})$ were added to the medium in separate experiments, or extracellular $\mathrm{Ca}^{2+}$ concentrations were lowered from $2 \mathrm{~mm}$ to $0.2 \mathrm{~mm}$ after $2 \mathrm{~h}$ control observations. The effects of each treatment were evaluated by dividing the number of $\mathrm{Ca}^{2+}$ transients and the distance traveled during the $2 \mathrm{~h}$ after the application of each reagent by the number of $\mathrm{Ca}^{2+}$ transients and the distance traveled during the first $2 \mathrm{~h}$ in the absence of each reagent. Each column represents the average change in the number of $\mathrm{Ca}^{2+}$ transients (black) or the migration rate (gray). $\boldsymbol{B}$, The effects of each treatment on the $\mathrm{Ca}^{2+}$ transient amplitude were evaluated in JOE control OPCs during $2 \mathrm{~h}$. Values are expressed as mean \pm SEM of at least three independent experiments. ${ }^{* *} p<0.01,{ }^{* * *} p<0.001$.

been well studied as sources of migrating OPCs. Our goal was to confirm the in vitro data with respect to rates of migration of OPCs out of the ventricular zone and into the corpus callosum using conditions established by others for such studies (Kakita and Goldman, 1999; Suzuki and Goldman, 2003). We tracked cell bodies of migrating GFP positive OPCs (OPC $\sim \mathrm{GFP}$ ) for a period of $12 \mathrm{~h}$ in the SVZ. In these time-lapse experiments cell movement was assessed by calculating the average cell migration velocity and the total distance traveled by the cell. Examples of such measurements are shown in Figure 10 A. Under these experimental conditions the mean rates of migration for JOE control and JOE OPCs in the SVZ were $27 \pm 3.4 \mu \mathrm{m} / \mathrm{h}$ and $43 \pm 3.1 \mu \mathrm{m} / \mathrm{h}$, respectively $(p<0.01)$. So the in vivo average cell migration velocity in golli overexpressing OPCs was significantly higher compared with that of the control group (Fig. 10D). As might be expected, there was also an increase in the total migration distance after $8 \mathrm{~h}$ (JOE Control: $180 \pm 37 \mu \mathrm{m}$, and JOE: $274 \pm 57$ $\mu \mathrm{m}, n=30$ cells, $p<0.01$ ). Conversely, a reduced migration velocity compared with controls was noted in golli $\mathrm{KO}$ cells, in which OPCs lacking golli appeared to migrate slower than control OPCs in vivo (Fig. 10E). Furthermore, and clearly indicating that VOCCs are essential for in vivo OPC migration, $15 \mathrm{~mm} \mathrm{~K}^{+}$ caused a significant increase in the average cell velocity in gollioverexpressing OPCs (Fig. 10D), and in both genotypes a complete inhibition of OPC migration was found in the presence of VOCC inhibitors (Fig. 10D,E).

A model for the data presented in this work is proposed in Figure 11. In the absence of golli, there is a significant decrease in the amplitude of $\mathrm{Ca}^{2+}$ transients as well as in the average frequency and amplitude of saltatory movement of migrating OPCs. In contrast, golli overexpression enhances activation of L-type VOCCs leading to increases in the amplitude of $\mathrm{Ca}^{2+}$ transients and accelerating OPC migration by promoting $\mathrm{Ca}^{2+}$ dependent soma translocation and leading process extension. It is not yet clear whether golli acts in a direct or indirect manner on the channel itself.

\section{Discussion}

Migration of glial cells from proliferation zones to their final position is an essential step in the development of the nervous system (Warrington et al., 1993; Goldman et al., 1997; Schmidt et al., 1997; Ivanova et al., 2003; Kessaris et al., 2006), yet the physiological mechanisms of glial cell migration are still largely unknown. A few studies on cultured OPCs and astrocytes indicate that $\mathrm{Ca}^{2+}$ signaling may contribute to migration in glial cells (Wang et al., 1996; Simpson and Armstrong, 1999; Matyash et al., 2002), and recent studies suggest that VOCCs generate $\mathrm{Ca}^{2+}$ signals that play a vital role in the migration of glial cells during the development of the insect antennal lobe (Lohr et al., 2005). Migration of cerebellar granule cells has also been shown to be dependent on voltage-gated $\mathrm{Ca}^{2+}$ signaling (Komuro and Rakic, 1992, 1998). Blocking N-type $\mathrm{Ca}^{2+}$ channels decreases the migration rate of granule cells in mouse cerebellar slices, while activating $\mathrm{Ca}^{2+}$ channels with high $\mathrm{K}^{+}$enhances migration (Komuro and Rakic, 1992, 1998).

Changes in intracellular $\mathrm{Ca}^{2+}$ play a critical role in the ability of OLs to maintain membrane sheets and processes (Benjamins and Nedelkoska, 1996). One property of golli proteins is their ability to induce OL cell lines to extend processes (Reyes and Campagnoni, 2002); and these processes then rapidly retract after a short exposure to depolarizing conditions. Retraction is accompanied by increased $\mathrm{Ca}^{2+}$ uptake in these cells, and several lines of evidence indicate that the effects of golli on process extension/ retraction are mediated through VOCC $\mathrm{Ca}^{2+}$ influx (Paez et al., 2007).

\section{Golli increases OPC migration}

Oligodendrocyte migration consists of cycles of movement interspersed with stationary periods. This characteristic has been described for neuronal progenitors in the cortex, cerebellum and hippocampus (Gasser and Hatten, 1990; O'Rourke et al., 1992; Luskin and Boone, 1994; Komuro and Rakic, 1995; Wichterle et al., 1997). Cells migrating along the SVZ-olfactory bulb pathway show similar interspersed periods of slower and higher rates of movement. We found similar results in our in vitro system; OPCs from golli KO and control mice as well as OPCs from JOE mice alternate between periods of higher and lower migration rates. The lower average speed that we found in KO OPCs was due to a reduction in the maximum speed together with an increase in the resting time. In the golli overexpressing JOE mice there was a significant increase in the average maximum speed but no change in the resting time during saltatory oscillations.

Our live imaging studies show that, like other migrating cells, OPCs have leading and trailing processes. The directed movement of OPCs typically requires three distinct steps: extension of 

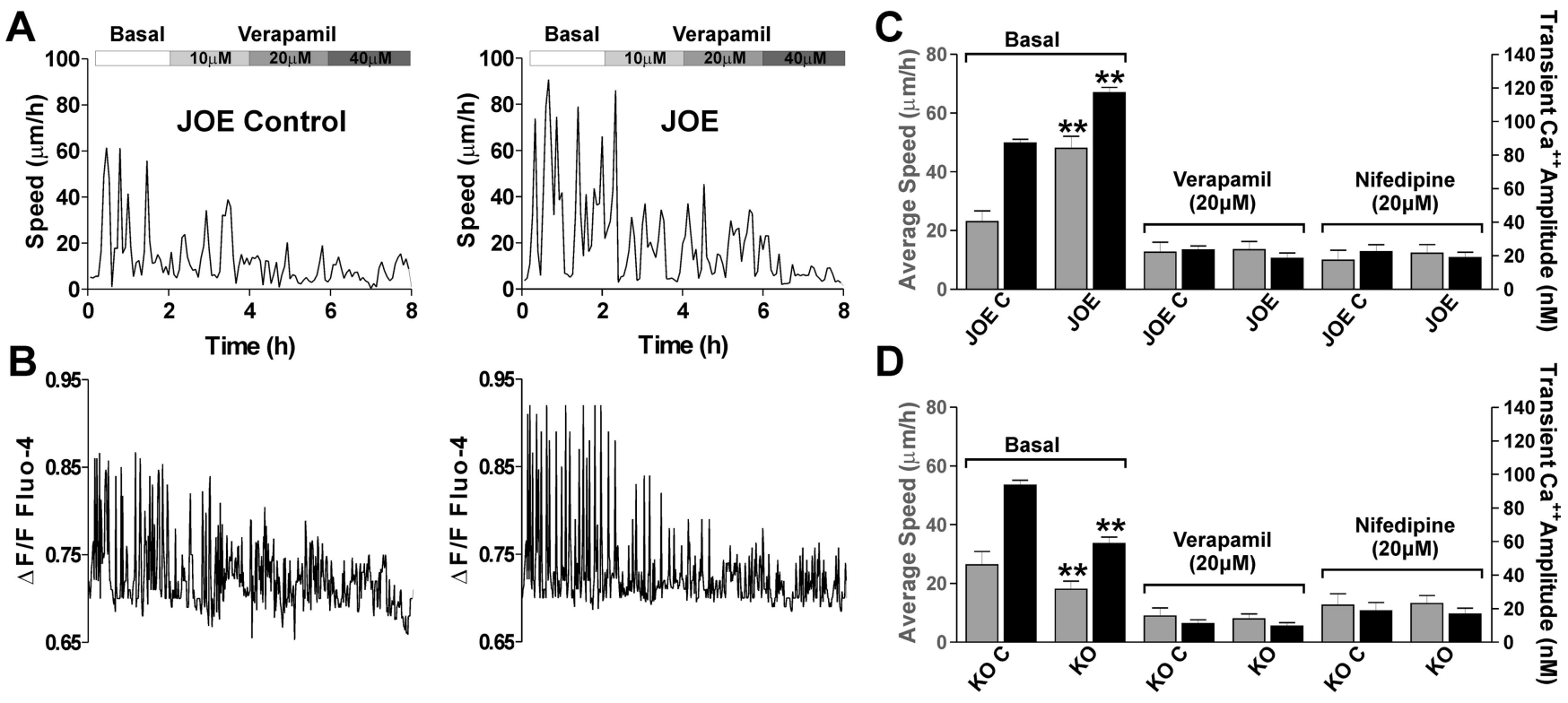

Figure 7. VOCCS are essential for enhanced migration of JOE cell. $\boldsymbol{A}$, Typical examples of JOE OPC saltatory movement in the presence of increasing concentrations of verapamil. $\boldsymbol{B}$, Sequential changes in the $\mathrm{Ca}^{2+}$ transients over time in the same cells are shown. Note that at the same time the addition of $20 \mu \mathrm{m}$ verapamil completely inhibited JOE cell movement and transient elevations of the $\left[\mathrm{Ca}^{2+}\right]_{\text {int. }} \boldsymbol{C}, \boldsymbol{D}$, Average migration speed (gray bars) and $\mathrm{Ca}^{2+}$ transients amplitude (black bars) obtained from golli $\mathrm{KO}$ and JOE OPCs bathed in control medium (basal) or in the presence of the VOCC inhibitors verapamil $(20 \mu \mathrm{M})$ and nifedipine $(20 \mu \mathrm{m})$ are shown. Values are expressed as mean \pm SEM of at least four independent experiments. ${ }^{* *} p<0.01$ versus control cells.
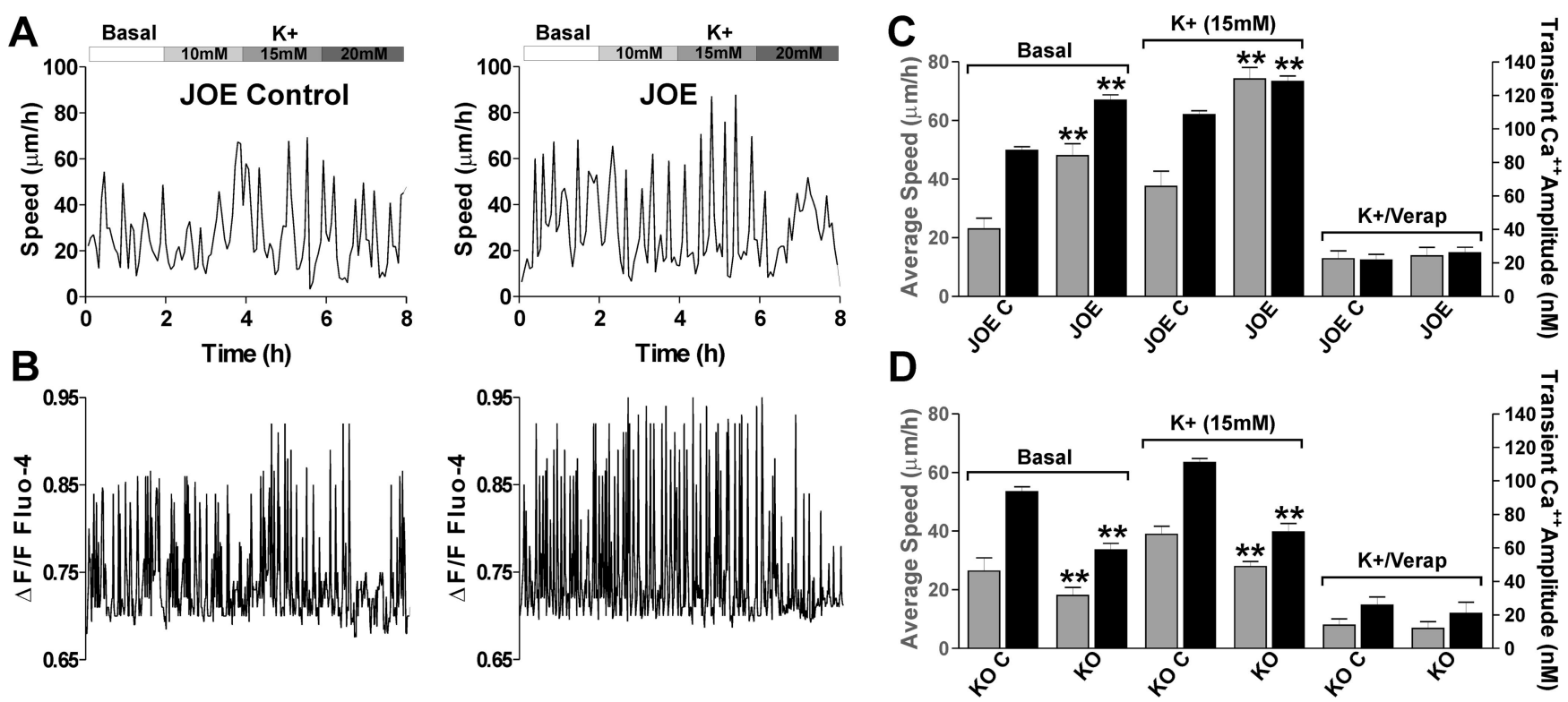

Figure 8. VOCCs modulate the rate of OPC migration. $A$, Effects of addition to the external medium of different concentrations of $\mathrm{K}^{+}$on JOE OPC saltatory movement. Note that the addition of $15 \mathrm{~mm} \mathrm{~K}^{+}$to the culture medium of $\mathrm{JOE}$ cells increases the maximum speed of saltatory movement. $B$, Sequential changes in the $\mathrm{Ca}^{2+}$ transients over time in the same cells. Note that the addition of 10 and $15 \mathrm{~mm} \mathrm{~K}^{+}$increased the amplitude of transient $\mathrm{Ca}^{2+}$ elevations in JOE cell. C, D, Average migration speed (gray bars) and $\mathrm{Ca}^{2+}$ transients amplitude (black bars) obtained from golli KO and JOE OPCs bathed in control medium (basal), $15 \mathrm{~mm} \mathrm{~K}^{+}$, or in the presence of $15 \mathrm{~mm} \mathrm{~K}^{+}$plus verapamil $(20 \mu \mathrm{M}$ ) are shown. Values are expressed as mean \pm SEM of at least four independent experiments. ${ }^{* *} p<0.01$ versus control cells.

the leading process, translocation of the soma/nucleus, and retraction of the trailing process. The leading process is headed by a growth cone-like structure similar to the motile axonal growth cone. Successful migration of the cell also requires the translocation of the soma, which involves the detachment of the somatic adhesion from the substrate and the movement of the nucleus (nucleokinesis). The analysis of the frequency and amplitude of saltatory movement suggest that leading process extension and nucleokinesis are faster in JOE OPCs than in JOE control or golli $\mathrm{KO}$ cells. This could explain the higher amplitude (i.e., difference between lowest and highest speed in the oscillation) found in JOE cells and the increase in the resting time between cycles of advancement in golli KO OPCs.

Our in vitro observations of cultured OPCs indicate that both the leading growth cone and the soma exhibit transient $\mathrm{Ca}^{2+}$ elevations during saltatory coordinated advancement. Previous data from our lab revealed the presence of golli clusters along OPC cell line processes in association with local regions of high transient $\mathrm{Ca}^{2+}$ uptake in growing processes (Paez et al., 2007). Transient local $\mathrm{Ca}^{2+}$ uptake along OPC processes is likely to be 
Table 1. Changes in the frequency and amplitude of saltatory movements and $\mathrm{Ca}^{2+}$ transients in golli $\mathrm{KO}$ and overexpressing OPCs under basal conditions or after the addition of $15 \mathrm{~mm} \mathrm{~K}^{+}$to the culture medium

\begin{tabular}{|c|c|c|c|c|c|}
\hline & & KO control & KO & JOE control & JOE \\
\hline \multicolumn{6}{|l|}{ Movement } \\
\hline \multirow[t]{2}{*}{ Frequency (cycles/h) } & Basal & $2.12 \pm 0.14$ & $1.41 \pm 0.20^{*}$ & $1.96 \pm 0.21$ & $2.01 \pm 0.18$ \\
\hline & $\mathrm{K}^{+}$activation & $2.42 \pm 0.27$ & $2.01 \pm 0.31^{*}$ & $2.50 \pm 0.30$ & $3.04 \pm 0.22^{*}$ \\
\hline \multirow[t]{2}{*}{ Amplitude ( $\mu \mathrm{m} / \mathrm{h})$} & Basal & $37 \pm 3$ & $28 \pm 2^{*}$ & $34 \pm 4$ & $63 \pm 5^{* *}$ \\
\hline & $\mathrm{K}^{+}$activation & $51 \pm 2$ & $33 \pm 2^{*}$ & $48 \pm 4$ & $85 \pm 3^{*}$ \\
\hline \multicolumn{6}{|l|}{$\mathrm{Ca}^{2+}$ transients } \\
\hline \multirow[t]{2}{*}{ Frequency (cycles/h) } & Basal & $15 \pm 2$ & $14 \pm 3$ & $16 \pm 1$ & $16 \pm 2$ \\
\hline & $\mathrm{K}^{+}$activation & $17 \pm 3$ & $16 \pm 2$ & $17 \pm 2$ & $17 \pm 2$ \\
\hline \multirow[t]{2}{*}{ Amplitude (nм) } & Basal & $93.5 \pm 3.1$ & $58.7 \pm 4.0^{* *}$ & $87.2 \pm 2.2$ & $117.2 \pm 3.1^{* *}$ \\
\hline & $\mathrm{K}^{+}$activation & $111 \pm 2.3$ & $69.5 \pm 5.1^{*}$ & $108.4 \pm 2.5$ & $128.4 \pm 3.2^{* *}$ \\
\hline
\end{tabular}

Values are expressed as mean \pm SEM. Asterisks in boldface values designate significant increase or decrease versus corresponding control cells: ${ }^{*} p<0.05$, ${ }^{* *} p<0.01$.

A

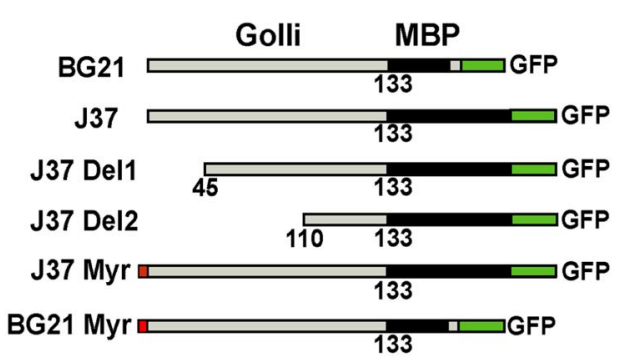

D

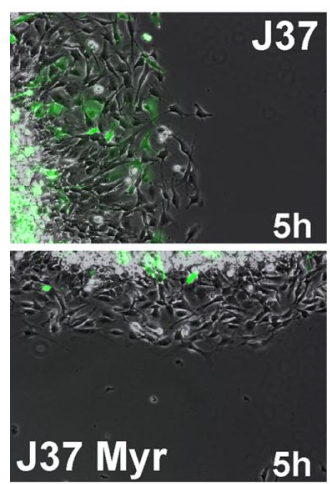

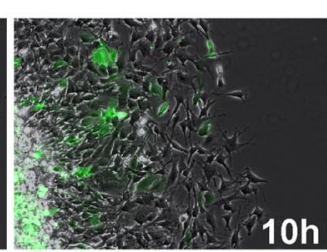

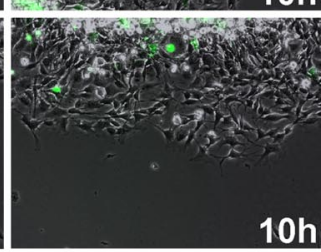

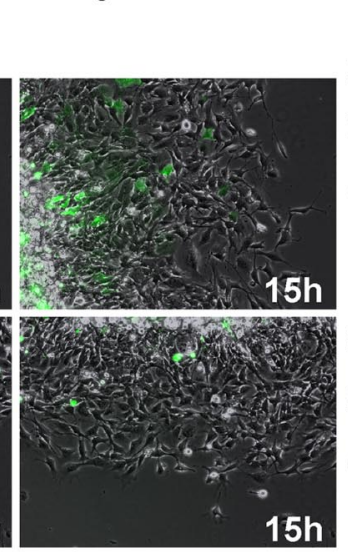
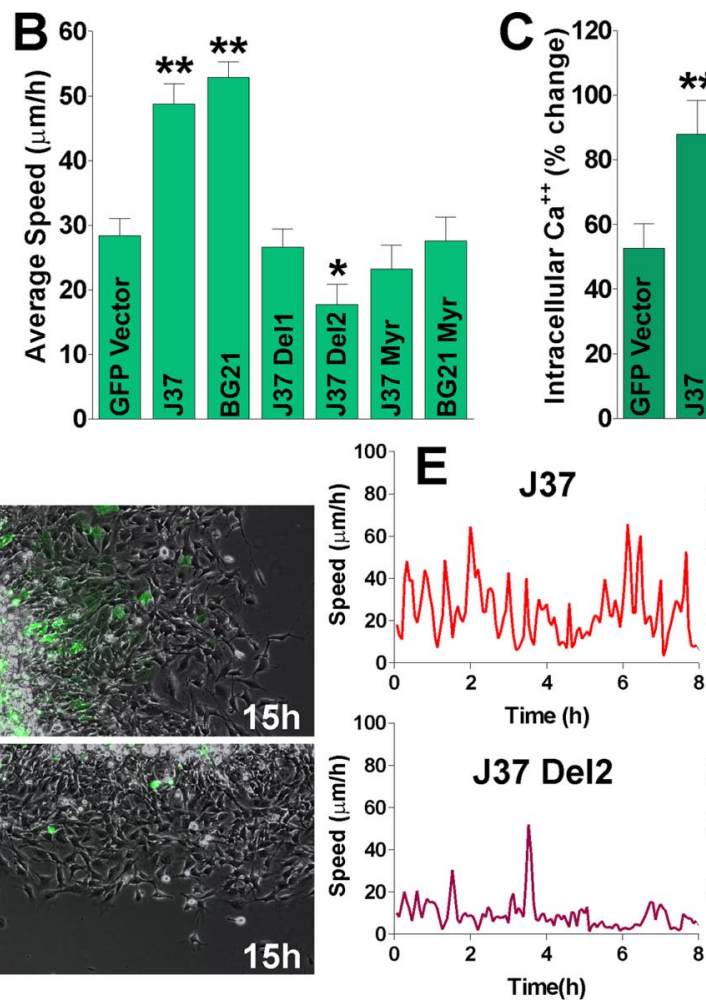
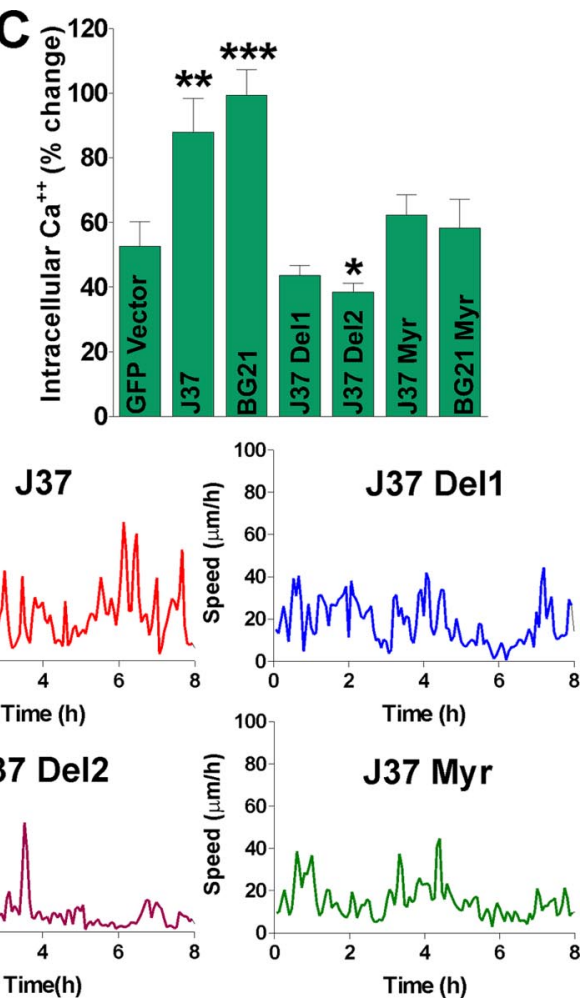

Figure 9. The golli myristoylation site is essential for the effect of golli on OPC migration. $A$, Diagram showing the golli-mbp::GFP constructs designed to examine the regions on the golli protein that might be responsible for the increase in OPC migration. The golli protein was divided into the MBP and golli domain to determine whether either region was responsible for the migration effect. Expression of the insert is under control of the cytomegalovirus (CMV) promoter. $\boldsymbol{B}$, The agarose drop assay was used to quantitatively analyze the average speed in migrating N19 cells overexpressing different golli-GFP constructs during $20 \mathrm{~h}$. C, $\mathrm{Ca}^{2+}$ uptake was stimulated in N19 cells overexpressing different golli-GPP constructs using high $\mathrm{K}^{+}$(15 mM). High K ${ }^{+}$was applied to N19 cells for $120 \mathrm{~s}$ by a fast and local perfusion system. The graphs shows the average amplitude calculated from the responding cells, expressed as percentage of change of the emission intensities. $\boldsymbol{D}$, Phase-contrast imaging of migrating N19 cells in an agarose drop assay during $15 \mathrm{~h}$. Scale bars, $50 \mu \mathrm{m}$. $\boldsymbol{E}$, Analysis of saltatory oscillations in migrating N19 cells transfected with different golli-GFP constructs shows that the overexpression of J37-Del1, Del2, and Myr drastically reduced the amplitude and frequency of speed oscillations in this cell line. Values are expressed as mean \pm SEM of at least four independent experiments. ${ }^{*} p<0.05,{ }^{* *} p<0.01,{ }^{* * *} p<0.001$ versus cells transfected with nonmodified GFP vector (GFP vector).

responsible for process elongation and subsequent OPC migration. We postulate that golli regulates spontaneous local $\mathrm{Ca}^{2+}$ influx during leading process growth and nucleokinesis accelerating OPC migration.

\section{Golli promotes in vivo OPC migration from the SVZ}

The role of $\mathrm{Ca}^{2+}$ in oligodendroglial cell migration has only been studied in cultured cells: Migration of cultured OPCs is enhanced by activation of receptors for glutamate or growth factors, and reduced by buffering intracellular calcium with BAPTA (Wang et al., 1996; Simpson and Armstrong, 1999). It has been shown, however, that the properties of cultured glial cells may differ from those in vivo (He et al., 1996; Kimelberg et al., 1997), and that cell migration depends on a variety of factors provided by the cellular environment found only in intact tissue, such as cell surface molecules and extracellular matrix molecules (Kramer et al., 2001; Sobeih and Corfas, 2002).

Most of gliogenesis takes place in the perinatal period (Luskin and McDermott, 1994; Zerlin et al., 1995). During this time, progenitors migrate radially out of the SVZ into the overlying white matter and cortex, or laterally through the white matter and then radially into the lateral cortex and striatum to develop into astrocytes and oligodendrocytes (Levison et al., 1993; Zerlin and Goldman, 1997). 

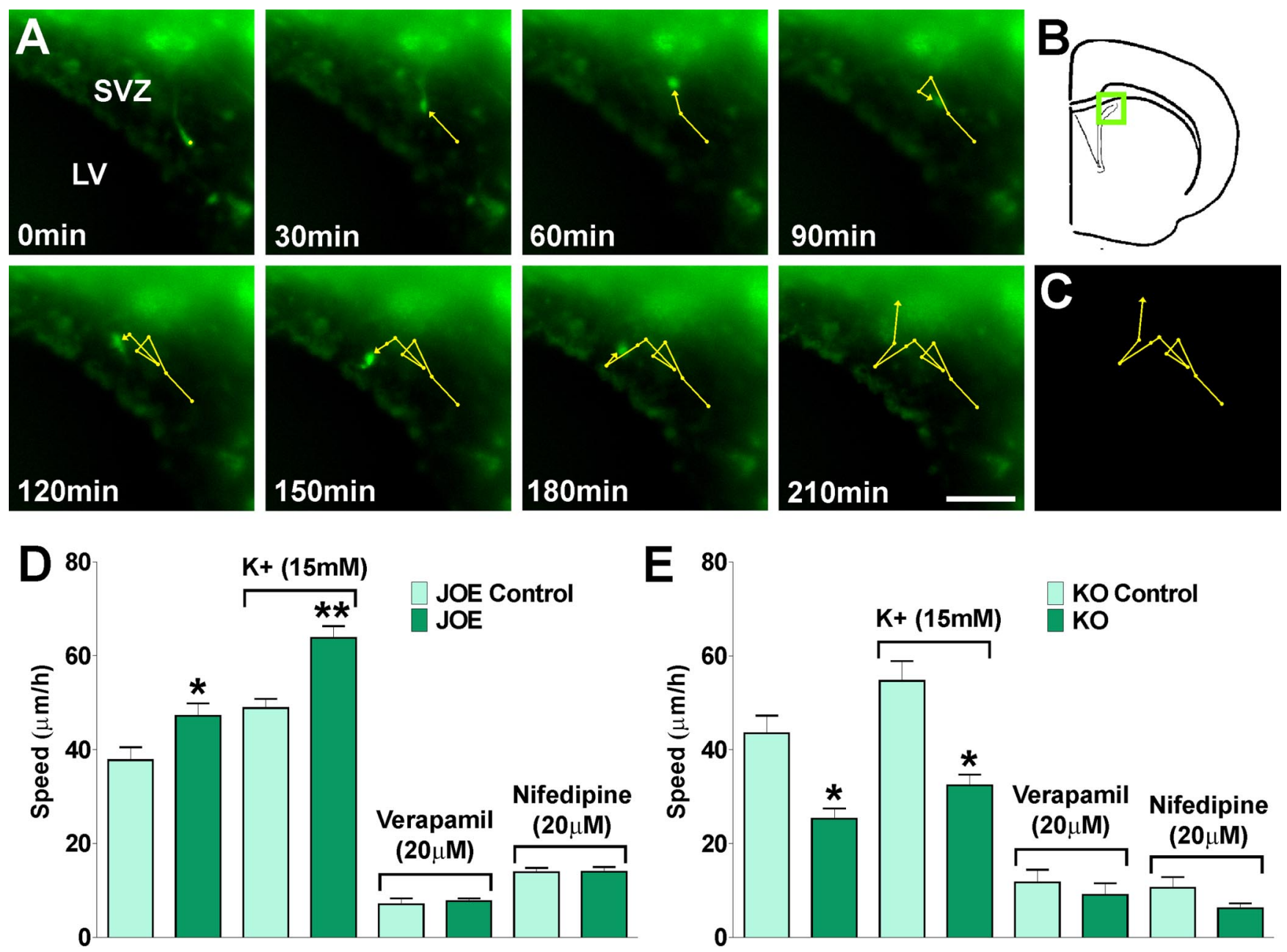

Figure 10. Migration of subventricular zone OPCs in living tissue. Brain slices were incubated in a stage top chamber with $5 \% \mathrm{CO}_{2}$ at $37^{\circ} \mathrm{C}$, which was placed on the stage of a spinning disc confocal inverted microscope. Fluorescent field images were obtained for brain slices with a specific GFP filter at 6 min intervals for a total of $12 \mathrm{~h}$. OPC tracking was started from a time point when a cell first came into focus or appeared at the edge of the imaging field and continued until it either went out of focus or left the imaging field. $A, B$, Time lapse series of a GFP-expressing OPC in the dorsolateral SVZ. Each frame represents a single section of a time lapse video sequence $(\boldsymbol{A})$. Time is denoted in minutes in the bottom left corner. The area of the dorsolateral $S V Z$ is indicated in the inset $(\boldsymbol{B})$. $\boldsymbol{C}$ A reconstruction of the paths of movement of the GFP-expressing OPC observed over the 210 min period. Each circle represents the position of the cell body, and, therefore, the length of the line between two circles represents the relative velocity of the cell at that moment. Cell migration speed and distances were analyzed off-line by tracing individual cells at different times. $\boldsymbol{D}, \boldsymbol{E}, 0 \mathrm{PC}$ average migration speed was calculated from at lest 40 cells in each experimental condition. Values are expressed as mean \pm SEM of at least four independent experiments. ${ }^{*} p<0.05,{ }^{* *} p<0.01$ versus control cells. LV, Lateral ventricle. Scale bar, $50 \mu \mathrm{m}$.

The present work shows that $\mathrm{Ca}^{2+}$ signaling seems to be essential for the in vivo migration of OPCs in the SVZ, and that golli acts to modulate this migration by exerting an influence over $\mathrm{Ca}^{2+}$ uptake in OPCs. Time-lapse measurement in tissue slices provided direct evidence that SVZ OPCs from JOE mice exhibited increased migratory distance and average speed compared with JOE control SVZ progenitors. Our in vivo and in vitro data, then, strongly support the conclusion that golli plays a role in regulating OPC migration.

\section{The effect of golli on OPCs velocity is mediated through} VOCC $\mathrm{Ca}^{2+}$ uptake

A role for transient $\mathrm{Ca}^{2+}$ elevations in controlling cell motility has been reported in various types of cells ranging from fibroblasts to immature neurons (Gomez and Spitzer, 1999; Chakraborty et al., 2003). Neuronal precursors and postmigratory neurons in the fetal cerebrum and the early postnatal cerebellum exhibit spontaneous $\mathrm{Ca}^{2+}$ transients (Owens and Kriegstein, 1998; Kumada and Komuro, 2004). The spontaneous $\mathrm{Ca}^{2+}$ transients in these migrating cells are mediated by NMDA receptors and N-type VOCCs (Komuro and Kumada, 2005).

In the present work $\mathrm{Ca}^{2+}$ imaging revealed different patterns of $\mathrm{Ca}^{2+}$ transients in the soma and processes of OPCs during different phases of saltatory movement. Movement and stationary states are tightly correlated with the peak and trough of the $\mathrm{Ca}^{2+}$ fluctuation, respectively, and the rate of soma translocation positively correlates with both the amplitude and frequency of $\mathrm{Ca}^{2+}$ transients under a variety of pharmacological treatments that perturb these transients. At present, little is known about how $\mathrm{Ca}^{2+}$ transients control the migration of immature oligodendroglial cells. $\mathrm{Ca}^{2+}$ transients may affect the recycling of celladhesion receptors, and induce the rearrangement of cytoskeletal components, which are essential for cell movement (Lawson and Maxfield, 1995).

Our results support the notion of a positive correlation between $\left[\mathrm{Ca}^{2+}\right]_{\text {int }}$ of OPCs and the rate of migration of these cells. The $\mathrm{Ca}^{2+}$ transient amplitude and the rate of cell movement observed in isolated JOE cells in culture were higher than that 
observed in control cells suggesting that the presence of golli may act to increase the generation of $\mathrm{Ca}^{2+}$ transients in OPCs. In OPC cell bodies, $\mathrm{Ca}^{2+}$ oscillations required the presence of external $\mathrm{Ca}^{2+}$ and were abolished in cells incubated with EGTA, verapamil and nifedipine, indicating that $\mathrm{Ca}^{2+}$ influx through VOCCs is essential for this phenomenon.

In agreement with our previous finding showing that golli increases $\mathrm{Ca}^{2+}$ influx after membrane depolarization (Paez et al., 2007), we found a significant increase in the migration speed of golli overexpressing OPCs versus controls after high $\mathrm{K}^{+}$treatment. Under this experimental condition the amplitude and frequency of saltatory movement as well as the amplitude of $\mathrm{Ca}^{2+}$ transient observed in isolated JOE cells were higher than those observed in control OPC cultures. However, there was a negative correlation between the presence of VOCC inhibitors in the media and the average migration speed of JOE cells. Golli-mediated modulation of OPC velocity disappeared when the VOCC antagonists, verapamil and nifedipine, were added to the external medium. These data confirm the participation of VOCCs in the modulation of OPC mobility, a novel concept in the migration of nonexcitable cells.

Evidence for a VOCC role in neuronal migration first came from imaging studies of granule cell migration in acute cerebellar slices, in which blockade or enhancement of $\mathrm{Ca}^{2+}$ influx through $\mathrm{N}$-type VOCCs reduced or promoted the rate of granule cell movement, respectively (Komuro and Rakic 1992, 1998). Interestingly, different VOCCs may be involved in $\mathrm{Ca}^{2+}$ signaling for axon extension and soma translocation in migrating neurons (Tam et al., 2000).

Oligodendroglial precursor cells exhibit many electrical properties characteristic of neurons: they express the neuronal type of $\mathrm{Na}^{+}$channels, $\mathrm{Ca}^{2+}$-activated as well as delayed and transient $\mathrm{K}^{+}$outward currents, and inwardly rectifying $\mathrm{K}^{+}$currents. They also express GABA receptors and are capable of firing action potentials (Sánchez-Gómez and Matute, 1999; Káradóttir et al., 2008; Paez et al., 2009). Our data show that golli facilitates voltage-mediated $\mathrm{Ca}^{2+}$ entry in the plasma membrane of migrating OPCs, however it is not yet known whether it does this through direct interaction with VOCCs or indirectly through interactions with other molecules or ion channels. Activation of GABA receptors leads to a depolarizing event sufficient to activate voltage-gated $\mathrm{Ca}^{2+}$ channels in OPCs (Kirchhoff and Kettenmann, 1992). However, our previously published data (Paez et al., 2007) suggest that golli is not affecting the activity of ionotropic or metabotropic glutamate receptors in cultured OPCs. Another possibility is that golli regulates VOCCs through modulation of $\mathrm{K}^{+}$channels, which are essential for maintaining the electrical properties of the plasma membrane in oligodendroglial cells (Butt and Kalsi, 2006). The possibility of golli influencing VOCCs through an action on $\mathrm{K}^{+}$channels remains to be explored.

We previously found that the golli effect on process extension/ retraction is mediated through L-type VOCC (Paez et al., 2007). In this study we provide evidence that golli-modulation of VOCCs increases the amplitude of spontaneous $\mathrm{Ca}^{2+}$ oscilla- tions in the soma and in the leading process of migrating OPCs. We postulate that golli modulation of L-type VOCC is accelerating cell migration by promoting $\mathrm{Ca}^{2+}$ dependent soma translocation and leading process formation. This mechanism points to a key role for golli proteins in the regulation of the rate of OPC migration through spontaneous $\mathrm{Ca}^{2+}$ oscillations, and for the first time provides evidence that functional voltage-gated $\mathrm{Ca}^{2+}$ channels are necessary for the migration of OPCs in vitro and in vivo.

\section{References}

Agresti C, Meomartini ME, Amadio S, Ambrosini E, Serafini B, Franchini L, Volonté C, Aloisi F, Visentin S (2005) Metabotropic P2 receptor activation regulates oligodendrocyte progenitor migration and development. Glia 50:132-144.

Amur-Umarjee S, Phan T, Campagnoni AT (1993) Myelin basic protein mRNA translocation in oligodendrocytes is inhibited by astrocytes in vitro. J Neurosci Res 36:99-110.

Benjamins JA, Nedelkoska L (1996) Release of intracellular calcium stores leads to retraction of membrane sheets and cell death in mature mouse oligodendrocytes. Neurochem Res 21:471-479.

Butt AM, Kalsi A (2006) Inwardly rectifying potassium channels (Kir) in central nervous system glia: a special role for Kir4.1 in glial functions. J Cell Mol Med 10:33-44.

Campagnoni AT, Pribyl TM, Campagnoni CW, Kampf K, Amur-Umarjee S, Landry CF, Handley VW, Newman SL, Garbay B, Kitamura K (1993) Structure and developmental regulation of Golli-mbp, a $105 \mathrm{~Kb}$ gene that encompasses the myelin basic protein gene and is expressed in cells in the oligodendrocyte lineage in the brain. J Biol Chem 268:4930-4938.

Chakraborty C, Barbin YP, Chakrabarti S, Chidiac P, Dixon SJ, Lala PK (2003) Endothelin-1 promotes migration and induces elevation of $\left[\mathrm{Ca}^{++}\right]_{\text {int }}$ and phosphorylation of MAP kinase of a human extravillous trophoblast cell line. Mol Cell Endocrinol 201:63-73.

Colwell CS (2000) Circadian modulation of calcium levels in cells in the suprachiasmatic nucleus. Eur J Neurosci 12:571-576.

Fay FS (1995) Calcium sparks in vascular smooth muscle: relaxation regulators. Science 270:588-589.

Feng JM, Hu YK, Xie LH, Colwell CS, Shao XM, Sun XP, Chen B, Tang H, Campagnoni AT (2006) Golli protein negatively regulates store depletion-induced calcium influx in T cells. Immunity 24:717-727.

Gasser UE, Hatten ME (1990) Neuron-glia interactions of rat hippocampal cells in vitro: glial-guided neuronal migration and neuronal regulation of glial differentiation. J Neurosci 10:1276-1285. 
Goldman SA, Nedergaard M, Crystal RG, Fraser RA, Goodman R, HarrisonRestelli C, Jiang J, Keyoung HM, Leventhal C, Pincus DW, Shahar A, Wang S (1997) Neural precursors and neuronal production in the adult mammalian forebrain. Ann N Y Acad Sci 835:30-55.

Gomez TM, Spitzer NC (1999) In vivo regulation of axon extension and pathfinding by growth-cone calcium transients. Nature 397:350-355.

Grynkiewicz G, Poenie M, Tsien RY (1985) A new generation of $\mathrm{Ca}^{++}$indicators with greatly improved fluorescence properties. J Biol Chem 260:3440-3450.

Gudz TI, Komuro H, Macklin WB (2006) Glutamate stimulates oligodendrocyte progenitor migration mediated via an $\alpha_{\mathrm{v}}$ integrin/myelin proteolipid protein complex. J Neurosci 26:2458-2466.

He M, Howe DG, McCarthy KD (1996) Oligodendroglial signal transduction systems are regulated by neuronal contact. J Neurochem 67:1491-1499.

Ivanova A, Nakahira E, Kagawa T, Oba A, Wada T, Takebayashi H, Spassky N, Levine J, Zalc B, Ikenaka K (2003) Evidence for a second wave of oligodendrogenesis in the postnatal cerebral cortex of the mouse. J Neurosci Res 73:581-592.

Jacobs EC, Pribyl TM, Feng JM, Kampf K, Spreur V, Campagnoni C, Colwell CS, Reyes SD, Martin M, Handley V, Hiltner TD, Readhead C, Jacobs RE, Messing A, Fisher RS, Campagnoni AT (2005) Region-specific myelin pathology in mice lacking the golli products of the myelin basic protein gene. J Neurosci 25:7004-7013.

Kakita A, Goldman JE (1999) Patterns and dynamics of SVZ cell migration in the postnatal forebrain: monitoring living progenitors in slice preparations. Neuron 23:461-472.

Káradóttir R, Hamilton NB, Bakiri Y, Attwell D (2008) Spiking and nonspiking classes of oligodendrocyte precursor glia in CNS white matter. Nat Neurosci 11:450-456.

Kessaris N, Fogarty M, Iannarelli P, Grist M, Wegner M, Richardson WD (2006) Competing waves of oligodendrocytes in the forebrain and postnatal elimination of an embryonic lineage. Nat Neurosci 9:173-179.

Kimelberg HK, Cai Z, Rastogi P, Charniga CJ, Goderie S, Dave V, Jalonen TO (1997) Transmitter-induced calcium responses differ in astrocytes acutely isolated from rat brain and in culture. J Neurochem 68:1088-1098.

Kirchhoff F, Kettenmann H (1992) GABA triggers a $\left[\mathrm{Ca}^{2+}\right]_{\mathrm{i}}$ increase in murine precursor cells of the oligodendrocyte lineage. Eur J Neurosci 4:1049-1058.

Kohama K, Ye LH, Hayakawa K, Okagaki T (1996) Myosin light chain kinase: an actin-binding protein that regulates an ATP-dependent interaction with myosin. Trends Pharmacol Sci 17:284-287.

Komuro H, Kumada T (2005) $\mathrm{Ca}^{++}$transients control CNS neuronal migration. Cell Calcium 37:387-393.

Komuro H, Rakic P (1992) Selective role of N-type calcium channels in neuronal migration. Science 257:806-809.

Komuro H, Rakic P (1995) Dynamics of granule cell migration: a confocal microscopic study in acute cerebellar slice preparations. J Neurosci 15:1110-1120.

Komuro H, Rakic P (1998) Distinct modes of neuronal migration in different domains of developing cerebellar cortex. J Neurosci 18:1478-1490.

Kramer SG, Kidd T, Simpson JH, Goodman CS (2001) Switching repulsion to attraction: changing responses to slit during transition in mesoderm migration. Science 292:737-740.

Kumada T, Komuro H (2004) Completion of neuronal migration regulated by loss of $\mathrm{Ca}^{++}$transients. Proc Natl Acad Sci U S A 101:8479-8484.

Landry CF, Ellison JA, Pribyl TM, Campagnoni C, Kampf K, Campagnoni AT (1996) Myelin basic protein gene expression in neurons: developmental and regional changes in protein targeting within neuronal nuclei, cell bodies, and processes. J Neurosci 16:2452-2462.

Lawson MA, Maxfield FR (1995) $\mathrm{Ca}^{++}$- and calcineurin-dependent recycling of an integrin to the front of migrating neutrophils. Nature 377:75-79.

Levison SW, Chuang C, Abramson BJ, Goldman JE (1993) The migrational patterns and developmental fates of glial precursors in the rat subventricular zone are temporally regulated. Development 119:611-622.

Lohr C, Heil JE, Deitmer JW (2005) Blockage of voltage-gated calcium signaling impairs migration of glial cells in vivo. Glia 50:198-211.

Luskin MB, Boone MS (1994) Rate and pattern of migration of lineallyrelated olfactory bulb interneurons generated postnatally in the subventricular zone of the rat. Chem Senses 19:695-714.
Luskin MB, McDermott K (1994) Divergent lineages for oligodendrocytes and astrocytes originating in the neonatal forebrain subventricular zone. Glia 11:211-226.

Mallon BS, Shick HE, Kidd GJ, Macklin WB (2002) Proteolipid promoter activity distinguishes two populations of NG2-positive cells throughout neonatal cortical development. J Neurosci 22:876-885.

Martin M, Reyes SD, Hiltner TD, Givogri MI, Tyszka JM, Fisher R, Campagnoni AT, Fraser SE, Jacobs RE, Readhead C (2007) T(2)-weighted microMRI and evoked potential of the visual system measurements during the development of hypomyelinated transgenic mice. [Special Issue for Anthony and Celia Campagnoni.] Neurochem Res 32:159-165.

Matyash M, Matyash V, Nolte C, Sorrentino V, Kettenmann H (2002) Requirement of functional ryanodine receptor type 3 for astrocyte migration. FASEB J 16:84-86.

Michel S, Itri J, Colwell CS (2002) Excitatory mechanisms in the suprachiasmatic nucleus: the role of AMPA/KA glutamate receptors. J Neurophysiol 88:817-828.

Milner R, Anderson HJ, Rippon RF, McKay JS, Franklin RJ, Marchionni MA, Reynolds R, Ffrench-Constant C (1997) Contrasting effects of mitogenic growth factors on oligodendrocyte precursor cell migration. Glia 19:85-90.

O'Rourke NA, Dailey ME, Smith SJ, McConnell SK (1992) Diverse migratory pathways in the developing cerebral cortex. Science 258:299-302.

Owens DF, Kriegstein AR (1998) Patterns of intracellular calcium fluctuation in precursor cells of the neocortical ventricular zone. J Neurosci 18:5374-5388.

Paez PM, Spreuer V, Handley V, Feng JM, Campagnoni C, Campagnoni AT (2007) Increased expression of golli myelin basic proteins enhances calcium influx into oligodendroglial cells. J Neurosci 27:12690-12699.

Paez PM, Fulton D, Colwell CS, Campagnoni AT (2009) Voltage-operated $\mathrm{Ca}^{2+}$ and $\mathrm{Na}^{+}$channels in the oligodendrocyte linage. J Neurosci Res, in press.

Paz Soldán MM, Warrington AE, Bieber AJ, Ciric B, Van Keulen V, Pease LR, Rodriguez M (2003) Remyelination-promoting antibodies activate distinct $\mathrm{Ca}^{++}$influx pathways in astrocytes and oligodendrocytes: relationship to the mechanism of myelin repair. Mol Cell Neurosci 22:14-24.

Pedrosa Ribeiro CM, Reece J, Putney JW Jr (1997) Role of the cytoskeleton in calcium signaling in NIH 3T3 cells. J Biol Chem 272:26555-26561.

Pribyl TM, Campagnoni CW, Kampf K, Kashima T, Handley VW, McMahon J, Campagnoni AT (1993) The human myelin basic protein gene is included within a 179-kilobase transcription unit: Expression in the immune and central nervous systems. Proc Natl Acad Sci USA 90:10695-10699.

Pribyl TM, Campagnoni CW, Kampf K, Ellison JA, Landry CF, Kashima T, McMahon J, Campagnoni AT (1996) Expression of the myelin basic protein gene locus in neurons and oligodendrocytes in the human fetal central nervous system. J Comp Neurol 374:342-353.

Reyes SD, Campagnoni AT (2002) Two separate domains in the golli myelin basic proteins are responsible for nuclear targeting and process extension in transfected cells. J Neurosci Res 69:587-596.

Reyes SD, Givogri MI, Campagnoni C, Kampf K, Handley V, Schonmann V and Campagnoni AT (2003) Over-expression of the golli J37 isoform in transgenic mice results in CNS hypomyelination. Soc Neurosci Abstr 29:141.7.

Sánchez-Gómez MV, Matute C (1999) AMPA and kainate receptors each mediate excitotoxicity in oligodendrocyte cultures. Neurobiol Dis 6:475-485.

Schmidt C, Ohlemeyer C, Labrakakis C, Walter T, Kettenmann H, Schnitzer J (1997) Analysis of motile oligodendrocyte precursor cells in vitro and in brain slices. Glia 20:284-298.

Simpson PB, Armstrong RC (1999) Intracellular signals and cytoskeletal elements involved in oligodendrocyte progenitor migration. Glia 26:22-35.

Sobeih MM, Corfas G (2002) Extracellular factors that regulate neuronal migration in the central nervous system. Int J Dev Neurosci 20:349-357.

Suzuki SO, Goldman JE (2003) Multiple cell populations in the early postnatal subventricular zone take distinct migratory pathways: a dynamic study of glial and neuronal progenitor migration. J Neurosci 23:4240-4250.

Suzumura A, Bhat S, Eccleston PA, Lisak RP, Silberberg DH (1984) The isolation and long-term culture of oligodendrocytes from newborn mouse brain. Brain Res 324:379-383.

Tam T, Mathews E, Snutch TP, Schafer WR (2000) Voltage-gated calcium 
channels direct neuronal migration in Caenorhabditis elegans. Dev Biol 226:104-117.

Varani J, Orr W, Ward PA (1978) A comparison of the migration patterns of normal and malignant cells in two assay systems. Am J Pathol 90:159-172.

Verity AN, Bredesen D, Vonderscher C, Handley VW, Campagnoni AT (1993) Expression of myelin protein genes and other myelin components in an oligodendrocytic cell line conditionally immortalized with a temperature-sensitive retrovirus. J Neurochem 60:577-587.

Wang C, Pralong WF, Schulz MF, Rougon G, Aubry JM, Pagliusi S, Robert A, Kiss JZ (1996) Functional $N$-methyl-D-aspartate receptors in O-2A glial precursor cells: a critical role in regulating polysialic acid-neural cell adhesion molecule expression and cell migration. J Cell Biol 135:1565-1581. Warrington AE, Barbarese E, Pfeiffer SE (1993) Differential myelinogenic capacity of specific developmental stages of the oligodendrocyte lineage upon transplantation into hypomyelinating hosts. J Neurosci Res 34:1-13.

Wichterle H, Garcia-Verdugo JM, Alvarez-Buylla A (1997) Direct evidence for homotypic, glia-independent neuronal migration. Neuron 18:779-791.

Zerlin M, Goldman JE (1997) Interactions between glial progenitors and blood vessels during early postnatal corticogenesis: blood vessel contact represents an early stage of astrocyte differentiation. J Comp Neurol 387:537-546.

Zerlin M, Levison SW, Goldman JE (1995) Early patterns of migration, morphogenesis, and intermediate filament expression of subventricular zone cells in the postnatal rat forebrain. J Neurosci 15:7238-7249. 